\title{
Thermodynamics of Standard Cells of the Saturated Cadmium Sulfate Type
}

\author{
Walter J. Hamer \\ Institute for Basic Standards, National Bureau of Standards, Washington, D.C. 20234
}

(December 21, 1971)

\begin{abstract}
This paper gives data on the thermodynamic functions of standard cells of the saturated cadmium sulfate type, as obtained from calorimetric and equilibrium data at $25{ }^{\circ} \mathrm{C}$ or from the electromotive forces (emfs) and emf-temperature coefficients of the cell for the temperature range of 0 to $43.6{ }^{\circ} \mathrm{C}$. The functions considered are the changes in Gibbs energy, enthalpy, entropy, and heat capacity for the cell reaction. The electromotive forces are expressed on the $V_{69}$ volt and the $t_{68}$ temperature scale. Results are expressed on the SI and for comparisons with literature data in terms of the defined thermochemical calorie. The effect of expressing the emf-temperature coefficient as a function of temperature in different ways on the values for the changes in entropy and heat capacity for the cell reaction is discussed. Finally, the observed emf of the standard cell at $25{ }^{\circ} \mathrm{C}$ is compared with emfs calculated from various values reported for the standard potentials of the cadmium-amalgam and mercury-mercurous sulfate electrodes and the activity coefficient of cadmium sulfate in saturated aqueous solution.
\end{abstract}

Key words: Emf-temperature coefficients of standard cells; emfs of standard cells; standard potential of standard cells; thermodynamics of standard cells.

\section{Introduction}

It is the purpose of this paper to present data on the thermodynamic functions of standard cells of the saturated cadmium sulfate type, ${ }^{1}$ as obtained from calorimetric and chemical equilibrium data, and to compare these data with those obtained from the electromotive force (emf) and emf-temperature coefficient of the cell. The thermodynamic functions considered are the changes in Gibbs energy (free energy), $\Delta G$; enthalpy (heat content), $\Delta H$; entropy, $\Delta S$; and heat capacity at constant pressure, $\Delta C_{p}$, where the changes are equal to the differences between the thermodynamic quantities of the products and the reactants of the cell reaction. Thermodynamically, these are given or are related by:

$$
\begin{aligned}
& \Delta G=\Delta H-T \Delta S=\Delta H+T[d(\Delta G) / d T]_{p} \\
& \Delta S=\int_{0}^{T} \Delta C_{p} d \ln T
\end{aligned}
$$

and

$$
\Delta C_{p}=[d(\Delta H) / d T]_{p}
$$

\footnotetext{
${ }^{1}$ Also referred to as the Weston cell after Edward Weston who invented the cell in 1892.
}

where $T$ is the Kelvin temperature (defined in the thermodynamic scale by assigning $273.16 \mathrm{~K}$ to the triple point of water; freezing point of water, $273.15 \mathrm{~K}[1]^{2}$ ).

The thermodynamic functions for a galvanic cell (or standard cell) may be obtained from its emf, $E$, and its emf-temperature coefficient, $d E / d T$, and are given by:

$$
\begin{aligned}
& \Delta G=-n E F \\
& \Delta H=-n E F+n F T(d E / d T) \\
& \Delta S=n F(d E / d T)
\end{aligned}
$$

and

$$
\Delta C_{p}=n F T\left(d^{2} E / d T^{2}\right)
$$

where $n$ is the number of equivalents involved in the cell reaction (in the present case $n$ is 2 ) and $F$ is the Faraday. $F$ has a value of 96487 coulombs per gramequivalent $[1,2,3,4]$ or 23060.9 calories per volt per gram-equivalent. ${ }^{3}$ Accordingly, a comparison may be made between the thermodynamics of the overall reaction of a standard cell as determined from calorimetric and chemical equilibrium data or from emf data.

\footnotetext{
${ }^{2}$ Figures in brackets indicate the literature references at the end of this paper.

${ }^{3}$ Based on the relation 1 thermochemical calorie (defined) $=4.1840 \mathrm{~J}[1]$.
} 


\section{The Standard Cell (saturated $\mathrm{CdSO}_{4}$ type)}

The conventional standard cell of the saturated cadmium sulfate type, ${ }^{4}$ considered here, may be represented by:

$$
\begin{array}{r}
(-) \mathrm{Cd}, \mathrm{Hg}(2 p)\left|\mathrm{CdSO}_{4} \cdot \frac{8}{3} \mathrm{H}_{2} \mathrm{O}(\mathrm{s})\right| \mathrm{CdSO}_{4}(\mathrm{ss}) \mid \mathrm{CdSO}_{4} \\
\cdot \frac{8}{3} \mathrm{H}_{2} \mathrm{O}(\mathrm{s})\left|\mathrm{Hg}_{2} \mathrm{SO}_{4}(\mathrm{~s})\right| \mathrm{Hg}(\mathrm{l})(+)
\end{array}
$$

where the vertical lines indicate the interface between two distinct phases (the amalgam consists of 2 phases, one solid and one liquid, but for simplicity vertical lines are not used in designating it), $2 p=2$ phases, ss = saturated solution, $\mathrm{s}=$ solid (or paste), and $\mathrm{l}=$ liquid. The cell reaction is [5]:

$$
\begin{gathered}
x \mathrm{Cd}, y \mathrm{Hg}(2 p)+\mathrm{Hg}_{2} \mathrm{SO}_{4}(\mathrm{~s})+\frac{8 / 3}{m-8 / 3} \mathrm{CdSO}_{4} \\
\cdot m \mathrm{H}_{2} \mathrm{O}(\mathrm{ss}) \rightarrow \frac{m}{m-8 / 3} \mathrm{CdSO}_{4} \\
\cdot \frac{8}{3} \mathrm{H}_{2} \mathrm{O}(\mathrm{s})+2 \mathrm{Hg}(\mathrm{l})+(x-1) \mathrm{Cd}, y \mathrm{Hg}(2 p)
\end{gathered}
$$

where $x$ moles of $\mathrm{Cd}$ are associated with $y$ moles of $\mathrm{Hg}$ in the amalgam and $m$ is the number of moles of water associated with 1 mole of $\mathrm{CdSO}_{4}$ in the saturated solution. Ten percent amalgams are now generally used, although there is now a trend to a return to the use of $12 \frac{1}{2}$-percent amalgams as they are more suitable for portable (or shippable) cells. At $25{ }^{\circ} \mathrm{C} m$ has a value of 15.089 [6].

The overall reaction for the cell may be considered as the sum of five reactions, namely:
(a)

$$
\mathrm{Cd}(\mathrm{s})+\mathrm{Hg}_{2} \mathrm{SO}_{4}(\mathrm{~s}) \rightarrow \mathrm{CdSO}_{4}(\mathrm{~s})+2 \mathrm{Hg}(\mathrm{l})
$$

$$
\mathrm{CdSO}_{4}(\mathrm{~s})+\mathrm{H}_{2} \mathrm{O}(\mathrm{l}) \rightarrow \mathrm{CdSO}_{4} \cdot \mathrm{H}_{2} \mathrm{O}(\mathrm{s})
$$
(c) $\mathrm{CdSO}_{4} \cdot \mathrm{H}_{2} \mathrm{O}(\mathrm{s})+\frac{5}{3} \mathrm{H}_{2} \mathrm{O}(\mathrm{l}) \rightarrow \mathrm{CdSO}_{4} \cdot \frac{8}{3} \mathrm{H}_{2} \mathrm{O}(\mathrm{s})$
(d) $\frac{8 / 3}{m-8 / 3} \mathrm{CdSO}_{4} \cdot m \mathrm{H}_{2} \mathrm{O}(\mathrm{ss}) \rightarrow \frac{8}{3} \mathrm{H}_{2} \mathrm{O}(\mathrm{l})$

$$
+\frac{8 / 3}{m-8 / 3} \mathrm{CdSO}_{4} \cdot \frac{8}{3} \mathrm{H}_{2} \mathrm{O}(\mathrm{s})
$$

and

(e)

$$
\mathrm{Cd}(10 \% \text { amalgam }) \rightarrow \mathrm{Cd}(\mathrm{s})
$$

\footnotetext{
${ }^{4}$ This is the type of standard cell presently used in the maintenance of the unit of emf in National Laboratories.
}

for which, reaction (e) excepted, calorimetric or thermal data are available.

\section{Calorimetric and Chemical Equilibrium Data}

\section{Reaction (a)}

For reaction (a) Cohen, Helderman, and Moesveld [7] obtained $-45,346 \mathrm{cal} \mathrm{mol}^{-1}$ at $18{ }^{\circ} \mathrm{C}$ for the difference between the heats of formation of $\mathrm{CdSO}_{4}$ and $\mathrm{Hg}_{2} \mathrm{SO}_{4}$; this difference is also equivalent to the heat of reaction (a) since the heats of formation of the elements, $\mathrm{Cd}$ and $\mathrm{Hg}$, in their standard states are zero. ${ }^{5}$ However, Cohen et al. arrived at their value for the heat of reaction (a) from combined calorimetric and emf data. They obtained their value by combining the value for the heat of solution of $\mathrm{CdSO}_{4}$ in water at $18{ }^{\circ} \mathrm{C}$ to give a solution 2.559 percent in $\mathrm{CdSO}_{4}$ with the value for the heat of reaction of an unsaturated standard cell $\left(2.559 \%\right.$ in $\left.\mathrm{CdSO}_{4}\right)$ which they obtained from the observed emf of the cell at $18{ }^{\circ} \mathrm{C}$ and the measured emftemperature coefficient of the cell at $18{ }^{\circ} \mathrm{C}$.

For our purpose, however, we need to obtain the heat of reaction (a) directly from calorimetric data. This heat value may be obtained from the heats of reaction of $\mathrm{Cd}$ and $\mathrm{CdSO}_{4}$ with other substances and of $\mathrm{Hg}$ and $\mathrm{Hg}_{2} \mathrm{SO}_{4}$ with other substances, as outlined by the following equations (unfortunately, most of the data were obtained many years ago). In these equations, the numbers in parentheses indicate, according to convention, the number of moles of water in which the substance is dissolved. Although, according to convention, the moles of water involved in dilution or solution [eqs (a4) and (a5) under $\mathrm{Cd}$ and $\mathrm{CdSO}_{4}$, for example] are not included in representing the reaction they are included here so that the equations balance, but are shown in parentheses with an asterisk to indicate that the heat of formation of water is not used in determining the heat of dilution or solution. Likewise, when the water contains KI or $\mathrm{KI}+\mathrm{I}_{2}$, it is also shown in parentheses with a superscript to indicate that the heat of formation of this water, containing $\mathrm{KI}$ or $\mathrm{KI}+\mathrm{I}_{2}$, is not used in determining the heat of dilution or solution (in the summation of the following reactions this quantity cancels). Also, in each case the values reported in calories were first converted to international joules using the factor used by the individual authors; these were then converted to absolute joules using the factor 1.000167 and these in turn were then converted (for comparison purposes) to calories using the presently accepted thermochemical definition of the calorie (see footnote 3 ) and are designated by the symbol $c f$ meaning conversion factor. Also in the equations that follow, $\mathrm{s}=$ solid, $\mathrm{l}=$ liquid, and $\mathrm{g}=$ gas. The numbers in parentheses after each value for $\Delta H$ denote the \pm uncertainty, discussed later.

5alorie is retained for the unit of energy when the literature is cited. More is given on this point including the use of SI later in this paper. The thermochemical calorie is presently defined in terms of the joule by the relation given in footnote 3 . 


\section{Cd and $\mathrm{CdSO}_{4}$}

(al) $\mathrm{Cd}(\mathrm{s})+2 \mathrm{HCl}(200) \rightarrow \mathrm{CdCl}_{2}(400)+\mathrm{H}_{2}(\mathrm{~g})$

$\Delta H_{1}\left(20^{\circ} \mathrm{C}\right) \quad=-17,230(70) \mathrm{cal} \mathrm{mol}^{-1}=-72,033(293) \mathrm{J} \mathrm{mol}^{-1}[8]$

$\Delta H_{1}\left(18^{\circ} \mathrm{C}\right) \quad=-17,290(90) \mathrm{cal} \mathrm{mol}^{-1}=-72,284(377) \mathrm{J} \mathrm{mol}^{-1}[8]$

$\Delta H_{1}\left(18{ }^{\circ} \mathrm{C}\right)^{\text {cf }} \quad=-17,276(90) \mathrm{cal} \mathrm{mol}^{-1}=-72,284(377) \mathrm{J} \mathrm{mol}^{-1}$

(a2) $\mathrm{CdCl}_{2}(400)+\mathrm{BaSO}_{4}(\mathrm{~s}) \rightarrow \mathrm{CdSO}_{4}(200)+\mathrm{BaCl}_{2}(200)$

$\Delta H_{2}\left(19^{\circ} \mathrm{C}\right) \quad=5,683(55) \mathrm{cal} \mathrm{mol}^{-1}=23,742(230) \mathrm{J} \mathrm{mol}^{-1}[9]$

$\Delta H_{2}\left(18^{\circ} \mathrm{C}\right) \quad=5,793(60) \mathrm{cal} \mathrm{mol}^{-1}=24,201(251) \mathrm{J} \mathrm{mol}^{-1}[10,11]$

$\Delta H_{2}\left(18^{\circ} \mathrm{C}\right)^{\mathrm{cf}} \quad=5,784(60) \mathrm{cal} \mathrm{mol}^{-1}=24,201(251) \mathrm{J} \mathrm{mol}^{-1}$

(a3) $\mathrm{BaCl}_{2}(400)+\mathrm{H}_{2} \mathrm{SO}_{4}(400) \rightarrow \mathrm{BaSO}_{4}(\mathrm{~s})+2 \mathrm{HCl}(400)$

$\Delta H_{3}\left(19^{\circ} \mathrm{C}\right) \quad=-9,152(55) \mathrm{cal} \mathrm{mol}^{-1}=-38,234(230) \mathrm{J} \mathrm{mol}^{-1}[9]$

$\Delta H_{3}\left(18^{\circ} \mathrm{C}\right) \quad=-9,262(60) \mathrm{cal} \mathrm{mol}^{-1}=-38,694(251) \mathrm{J} \mathrm{mol}^{-1}[10,11]$

$\Delta H_{3}\left(18{ }^{\circ} \mathrm{C}\right)^{\mathrm{cf}} \quad=-9,248(60) \mathrm{cal} \mathrm{mol}^{-1}=-38,694(251) \mathrm{J} \mathrm{mol}^{-1}$

(a4) $\mathrm{BaCl}_{2}(200)+\left(200 \mathrm{H}_{2} \mathrm{O}\right)^{*} \rightarrow \mathrm{BaCl}_{2}(400)$

$\Delta H_{4}\left(18^{\circ} \mathrm{C}\right) \quad=-50(1) \mathrm{cal} \mathrm{raol}^{-1}=-209(4) \mathrm{J} \mathrm{mol}^{-1}[12]$

$\Delta H_{4}\left(18{ }^{\circ} \mathrm{C}\right)^{\mathrm{cf}} \quad=-50(1) \mathrm{ca}^{l} \mathrm{~mol}^{-1}=-209(4) \mathrm{J} \mathrm{mol}^{-1}$

(a5) $2 \mathrm{HCl}(400) \rightarrow 2 \mathrm{HCl}(200)+\left(400 \mathrm{H}_{2} \mathrm{O}\right)^{*}$

$\Delta H_{5}\left(18{ }^{\circ} \mathrm{C}\right) \quad=120(2) \mathrm{cal} \mathrm{mol}^{-1}=502(8) \mathrm{J} \mathrm{mol}^{-1}[12]$

$\Delta H_{5}\left(18^{\circ} \mathrm{C}\right)^{\mathrm{cf}}=120(2) \mathrm{cal} \mathrm{mol}^{-1}=502(8) \mathrm{J} \mathrm{mol}^{-1}$

(a6) $\mathrm{H}_{2} \mathrm{SO}_{4}(222)+\left(178 \mathrm{H}_{2} \mathrm{O}\right)^{*} \rightarrow \mathrm{H}_{2} \mathrm{SO}_{4}(400)$

$\Delta H_{6}\left(18^{\circ} \mathrm{C}\right) \quad=-303(3) \mathrm{cal} \mathrm{mol}^{-1}=-1,268(12) \mathrm{J} \mathrm{mol}^{-1}[12]$

$\Delta H_{6}\left(18^{\circ} \mathrm{C}\right)^{\mathrm{cf}} \quad=-303(3) \mathrm{cal} \mathrm{mol}^{-1}=-1,268(12) \mathrm{J} \mathrm{mol}^{-1}$

(a7) $\mathrm{CdSO}_{4}(400) \rightarrow \mathrm{CdSO}_{4}(\mathrm{~s})+\left(400 \mathrm{H}_{2} \mathrm{O}\right)^{*}$

$\Delta H_{7}\left(18^{\circ} \mathrm{C}\right) \quad=10,690(25) \mathrm{cal} \mathrm{mol}^{-1}=44,756(105) \mathrm{J} \mathrm{mol}^{-1}[7]$

$\Delta H_{7}\left(18^{\circ} \mathrm{C}\right)^{\mathrm{cf}} \quad=10,697(25) \mathrm{cal} \mathrm{mol}^{-1}=44,756(105) \mathrm{J} \mathrm{mol}^{-1}$

(a8) $\mathrm{CdSO}_{4}(200)+\left(200 \mathrm{H}_{2} \mathrm{O}\right)^{*} \rightarrow \mathrm{CdSO}_{4}(400)$

$\Delta H_{8}\left(18{ }^{\circ} \mathrm{C}\right) \quad=-206(2) \mathrm{cal} \mathrm{mol}^{-1}=-862(8) \mathrm{J} \mathrm{mol}^{-1}[12]$

$\Delta H_{8}\left(18{ }^{\circ} \mathrm{C}\right)^{\text {cf }}=-206(2) \mathrm{cal} \mathrm{mol}^{-1}=-862(8) \mathrm{J} \mathrm{mol}^{-1}$

sum: $\mathrm{Cd}(\mathrm{s})+\mathrm{H}_{2} \mathrm{SO}_{4}(222) \rightarrow \mathrm{CdSO}_{4}(\mathrm{~s})+\mathrm{H}_{2}(\mathrm{~g})+\left(222 \mathrm{H}_{2} \mathrm{O}\right) *$

$\Delta H_{1-8}\left(18^{\circ} \mathrm{C}\right)^{\mathrm{cf}}=-10,482(69) \mathrm{cal} \mathrm{mol}^{-1}=-43,858(289) \mathrm{J} \mathrm{mol}^{-1}$

\section{$\mathrm{Hg}$ and $\mathrm{Hg}_{2} \mathrm{SO}_{4}$}

(a9) $\mathrm{Hg}_{2} \mathrm{SO}_{4}(\mathrm{~s})+2 \mathrm{KI}(694){ }^{\#} \rightarrow \mathrm{Hg}(\mathrm{l})+\mathrm{HgI}_{2}(694)$ \# $+\mathrm{K}_{2} \mathrm{SO}_{4}(694)$ \#

\# - contains 5.25 moles of KI

$\Delta H_{9}\left(14{ }^{\circ} \mathrm{C}\right) \quad=-44,100(560) \mathrm{cal} \mathrm{mol}^{-1}=-184,236(2339) \mathrm{J} \mathrm{mol}^{-1}[13]$

(a10) $\mathrm{HgI}_{2}(858)^{\phi} \rightarrow \mathrm{Hg}(\mathrm{l})+\mathrm{I}_{2}(858)^{\phi}$

$\phi$-contains 6.5 moles of $\mathrm{KI}$ and 1.0 mole of $\mathrm{I}_{2}$

$\Delta H_{10}\left(14{ }^{\circ} \mathrm{C}\right) \quad=31,300(400) \mathrm{cal} \mathrm{mol}^{-1}=130,762(1671) \mathrm{J} \mathrm{mol}^{-1}[13]$ 
(all) $\mathrm{I}_{2}(858)^{\phi} \rightarrow \mathrm{I}_{2}(\mathrm{~s})+\left(858 \mathrm{H}_{2} \mathrm{O}\right)^{\phi *}$

${ }^{\phi}$ - contains 6.5 moles of KI and 1.0 mole of $\mathrm{I}_{2}$

, $\Delta H_{11}\left(14^{\circ} \mathrm{C}\right)=-200(2) \mathrm{cal} \mathrm{mol}^{-1}=-835(8) \mathrm{J} \mathrm{mol}^{-1}[13]$

sum of (a9), (al0), and (al1): $\mathrm{Hg}_{2} \mathrm{SO}_{4}(\mathrm{~s})+2 \mathrm{KI}(694)^{*}+\mathrm{HgI}_{2}(858) \rightarrow$

$2 \mathrm{Hg}(1)+\mathrm{HgI}_{2}(1123)^{\alpha}+\mathrm{K}_{2} \mathrm{SO}_{4}(1123)^{\alpha}+\mathrm{I}_{2}(\mathrm{~s})$

$\alpha$-contains 8.5 moles of KI and 0.5 mole of $\mathrm{I}_{2}$

$\Delta H_{9-11}\left(14{ }^{\circ} \mathrm{C}\right)=-13,000(162) \mathrm{cal} \mathrm{mol}^{-1}=-54,309(676) \mathrm{J} \mathrm{mol}^{-1}$

$\Delta H_{9-11}\left(18^{\circ} \mathrm{C}\right)=-12,844(172) \mathrm{cal} \mathrm{mol}^{-1}=-53,658(718) \mathrm{J} \mathrm{mol}^{-1}[10,11,14,15]$

$\Delta H_{9-11}\left(18{ }^{\circ} \mathrm{C}\right)^{\mathrm{cf}}=-12,825(172) \mathrm{cal} \mathrm{mol}^{-1}=-53,658(720) \mathrm{J} \mathrm{mol}^{-1}$

(al2) $\mathrm{HgI}_{2}(1123)^{\alpha} \rightarrow \mathrm{HgI}_{2}(858)^{\phi}+\left(265 \mathrm{H}_{2} \mathrm{O}\right)^{\beta *}$

$\beta$-contains 2 moles of KI

$\Delta H_{12}\left(18^{\circ} \mathrm{C}\right) \quad=-2(0.1) \mathrm{cal} \mathrm{mol}^{-1}=-8(0.4) \mathrm{J} \mathrm{mol}^{-1}[12]$

$\Delta H_{12}\left(18{ }^{\circ} \mathrm{C}\right)^{\mathrm{cf}}=-2(0.1) \mathrm{cal} \mathrm{mol}^{-1}=-8(0.4) \mathrm{J} \mathrm{mol}^{-1}$

(a13) $\mathrm{Cl}_{2}(\mathrm{~g})+\mathrm{H}_{2}(\mathrm{~g}) \rightarrow 2 \mathrm{HCl}(\mathrm{g})$

$\Delta H_{13}\left(18{ }^{\circ} \mathrm{C}\right) \quad=-44.120(24) \mathrm{cal} \mathrm{mol}^{-1}=-184.644(100) \mathrm{J} \mathrm{mol}^{-1}[16]$

$\Delta H_{13}\left(18^{\circ} \mathrm{C}\right)^{\mathrm{cf}} \cdot=-44,131(24) \mathrm{cal} \mathrm{mol}^{-1}=-184,644(100) \mathrm{J} \mathrm{mol}^{-1}$

$\left(\right.$ a14) $\mathrm{I}_{2}(\mathrm{~s})+2 \mathrm{HCl}(\mathrm{g}) \rightarrow 2 \mathrm{HI}(\mathrm{g})+\mathrm{Cl}_{2}(\mathrm{~g})$

$\Delta H_{14}\left(22^{\circ} \mathrm{C}\right) \quad=55.933(100) \mathrm{cal} \mathrm{mol}^{-1}=233,985(418) \mathrm{J} \mathrm{mol}^{-1}[17]$

$\Delta H_{14}\left(18{ }^{\circ} \mathrm{C}\right) \quad=55,949(110) \mathrm{cal} \mathrm{mol}^{-1}=234,053(460) \mathrm{J} \mathrm{mol}^{-1}[10,18]$

$\Delta H_{14}\left(18^{\circ} \mathrm{C}\right)^{\mathrm{cf}}=55,940(110) \mathrm{cal} \mathrm{mol}^{-1}=234,053(460) \mathrm{J} \mathrm{mol}^{-1}$

(a15) $2 \mathrm{HI}(\mathrm{g})+\left(222 \mathrm{H}_{2} \mathrm{O}\right)^{*} \rightarrow 2 \mathrm{HI}(111)$

$\Delta H_{15}\left(18^{\circ} \mathrm{C}\right) \quad=-38,344(50) \mathrm{cal} \mathrm{mol}^{-1}=-160,431(209) \mathrm{J} \mathrm{mol}^{-1}[12]$

$\Delta H_{15}\left(18{ }^{\circ} \mathrm{C}\right)^{\mathrm{cf}}=-38,344(50) \mathrm{cal} \mathrm{mol}^{-1}=-160,431(209) \mathrm{J} \mathrm{mol}^{-1}$

(al6) $2 \mathrm{HI}(100)+2 \mathrm{KOH}(100) \rightarrow 2 \mathrm{KI}(200)+2 \mathrm{H}_{2} \mathrm{O}(1)$

$\Delta H_{16}\left(20^{\circ} \mathrm{C}\right) \quad=-27,830(20) \mathrm{cal} \mathrm{mol}^{-1}=-116,349(84) \mathrm{J} \mathrm{mol}^{-1}[19]$

$\Delta H_{16}\left(18^{\circ} \mathrm{C}\right) \quad=-28,034(29) \mathrm{cal} \mathrm{mol}^{-1}=-117,202(121) \mathrm{J} \mathrm{mol}^{-1}[19]$

$\Delta H_{16}\left(18^{\circ} \mathrm{C}\right)^{\mathrm{cf}}=-28,012(29) \mathrm{cal} \mathrm{mol}^{-1}=-117,202(121) \mathrm{J} \mathrm{mol}^{-1}$

$($ al7 $) 2 \mathrm{KOH}(111)+2 \mathrm{HI}(111)+2 \mathrm{KI}(200) \rightarrow 2 \mathrm{KOH}(100)+2 \mathrm{HI}(100)+2 \mathrm{KI}(222)$

$\Delta H_{17}\left(18^{\circ} \mathrm{C}\right) \quad=16(1) \mathrm{cal} \mathrm{mol}^{-1}=67(4) \mathrm{J} \mathrm{mol}^{-1}[12]$

$\Delta H_{17}\left(18{ }^{\circ} \mathrm{C}\right)^{\mathrm{cf}}=16(1) \mathrm{cal} \mathrm{mol}^{-1}=67(4) \mathrm{J} \mathrm{mol}^{-1}$

(a18) $2 \mathrm{KI}(222)+\left(944 \mathrm{H}_{2} \mathrm{O}\right)^{\gamma *} \rightarrow 2 \mathrm{KI}(694)^{*}$

$\gamma$-contains 10.5 moles of KI

$\Delta H_{18}\left(18^{\circ} \mathrm{C}\right) \quad=115(1) \mathrm{cal} \mathrm{mol}^{-1}=481(4) \mathrm{J} \mathrm{mol}^{-1}[12]$

$\Delta H_{18}\left(18^{\circ} \mathrm{C}\right)^{\mathrm{cf}}=115(1) \mathrm{cal} \mathrm{mol}^{-1}=481(4) \mathrm{J} \mathrm{mol}^{-1}$

(a19) $\mathrm{K}_{2} \mathrm{SO}_{4}(277.5)+2 \mathrm{H}_{2} \mathrm{O}(\mathrm{l}) \rightarrow \mathrm{H}_{2} \mathrm{SO}_{4}(55.5)+2 \mathrm{KOH}(111)$

$\Delta H_{19}\left(17^{\circ} \mathrm{C}\right) \quad=32,966(300) \mathrm{cal} \mathrm{mol}^{-1}=137,930(1255) \mathrm{J}^{-10 l}{ }^{-1}[20]$

$\Delta H_{19}\left(18{ }^{\circ} \mathrm{C}\right) \quad=32,907(310) \mathrm{cal} \mathrm{mol}^{-1}=137,683(1297) \mathrm{J} \mathrm{mol}^{-1}[10,14,15]$

$\Delta H_{19}\left(18^{\circ} \mathrm{C}\right)^{\text {cf }}=32,907(310) \mathrm{cal} \mathrm{mol}^{-1}=137,683(1297) \mathrm{J} \mathrm{mol}^{-1}$ 
(a20) $\mathrm{H}_{2} \mathrm{SO}_{4}(55.5)+\left(166.5 \mathrm{H}_{2} \mathrm{O}\right) * \rightarrow \mathrm{H}_{2} \mathrm{SO}_{4}(222)$

$\Delta H_{20}\left(18{ }^{\circ} \mathrm{C}\right) \quad=-390(10) \mathrm{cal} \mathrm{mol}^{-1}=-1,632(42) \mathrm{J} \mathrm{mol}^{-1}[12]$

$\Delta H_{20}\left(18{ }^{\circ} \mathrm{C}\right)^{\mathrm{cf}}=-390(10) \mathrm{cal} \mathrm{mol}^{-1}=-1,632(42) \mathrm{J} \mathrm{mol}^{-1}$

$\left(\right.$ a21) $\mathrm{K}_{2} \mathrm{SO}_{4}(1123) \rightarrow \mathrm{K}_{2} \mathrm{SO}_{4}(277.5)+\left(845.5 \mathrm{H}_{2} \mathrm{O}\right)^{\delta *}$

$\delta$ - contains 8.5 moles of KI

$$
\begin{array}{ll}
\Delta H_{21}\left(18^{\circ} \mathrm{C}\right) & =-195(2) \mathrm{cal} \mathrm{mol}^{-1}=-816(8) \mathrm{J} \mathrm{mol}^{-1}[12] \\
\Delta H_{21}\left(18{ }^{\circ} \mathrm{C}\right)^{\mathrm{cf}} & =-195(2) \mathrm{cal} \mathrm{mol}^{-1}=-816(8) \mathrm{J} \mathrm{mol}^{-1}
\end{array}
$$

sum: $\mathrm{Hg}_{2} \mathrm{SO}_{4}(\mathrm{~s})+\mathrm{H}_{2}(\mathrm{~g})+\left(222 \mathrm{H}_{2} \mathrm{O}\right)^{*} \rightarrow 2 \mathrm{Hg}(\mathrm{l})+\mathrm{H}_{2} \mathrm{SO}_{4}(222)$

$$
\Delta H_{9-21}\left(18^{\circ} \mathrm{C}\right)^{\mathrm{cf}}=-34,921(135) \mathrm{cal} \mathrm{mol}^{-1}=-146,109(565) \mathrm{J} \mathrm{mol}^{-1}
$$

\section{$\mathrm{Cd}, \mathrm{CdSO}_{4}-\mathrm{Hg}_{2} \mathrm{SO}_{4}, \mathrm{Hg}$}

sum: $\mathrm{Cd}(\mathrm{s})+\mathrm{Hg}_{2} \mathrm{SO}_{4}(\mathrm{~s}) \rightarrow \mathrm{CdSO}_{4}(\mathrm{~s})+2 \mathrm{Hg}(\mathrm{l})$

$$
\begin{aligned}
\Delta H_{1-21}\left(18{ }^{\circ} \mathrm{C}\right){ }^{\mathrm{cf}} & =-45,403(66) \mathrm{cal} \mathrm{mol}^{-1}=-189,967(276) \mathrm{J} \mathrm{mol}^{-1} \\
& =-45,403(397) \mathrm{cal} \mathrm{mol}^{-1}=-189,967(1661) \mathrm{J} \mathrm{mol}^{-1}
\end{aligned}
$$

It should be noted here that two uncertainties are given; these are discussed later under overall uncertainties. This value for $\Delta H_{1-21}\left(18{ }^{\circ} \mathrm{C}\right)^{\mathrm{cf}}$ may be converted to a value at $25^{\circ} \mathrm{C}$ by using known values of the heat capacities of $\mathrm{Cd}(\mathrm{s})$ [10], $\mathrm{Hg}_{2} \mathrm{SO}_{4}(\mathrm{~s})$ [14], $\mathrm{CdSO}_{4}(\mathrm{~s})[21,22]$ and $\mathrm{Hg}(1)$ [14], as a function of temperature, namely ${ }^{6}$ :

$$
\begin{array}{ll}
C_{p}[\mathrm{Cd}(\mathrm{s})] & =(5.333+0.00294 \mathrm{~T}) \mathrm{cal} \mathrm{mol}^{-1} \\
C_{p}\left[\mathrm{Hg}_{2} \mathrm{SO}_{4}(\mathrm{~s})\right] & =(13.8+0.060 T) \mathrm{cal} \mathrm{mol}^{-1} \\
C_{p}[\mathrm{CdSO}(\mathrm{s})] & =(10.771+0.0437 T) \mathrm{cal} \mathrm{mol}^{-1} \\
C_{p}[\mathrm{Hg}(\mathrm{l})] & =(7.368-0.0023 T) \mathrm{cal} \mathrm{mol}^{-1} \\
\Delta C_{p}[\operatorname{reaction}(\mathrm{a})] & =(6.374-0.02384 T) \mathrm{cal} \mathrm{mol}^{-1}
\end{array}
$$

all of which may be expressed in $\mathrm{J} \mathrm{mol}^{-1}$ using the relation given in footnote 3 . The heat of reaction (a) at $25{ }^{\circ} \mathrm{C}$ is then found to be $-45,407 \mathrm{cal} \mathrm{mol}^{-1}$ or $-189,983 \mathrm{~J} \mathrm{mo1}^{-1}$. Incidentally, the data of Bichowsky and Rossini [12] for the overall reaction lead to $-45,720$ cal mol-1 at $18{ }^{\circ} \mathrm{C}$ or $-45,716 \mathrm{cal} \mathrm{mol}^{-1}$ at $25^{\circ} \mathrm{C}$ (on the presently accepted definition of the calorie) for $\Delta H$ for reaction (a); NBS Circular 500 [23] gives $-44,021 \mathrm{cal} \mathrm{mol}^{-1}$ at $25{ }^{\circ} \mathrm{C}$ while revised NBS Circular [24] gives $-45,450 \mathrm{cal} \mathrm{mol}^{-1}$; this last value agrees within $43 \mathrm{cal} \mathrm{mol}^{-1}$ of the overall sum given above. These latter values $[12,23,24]$ are combinations of heat and emf data.

Notes on some of the above reactions should be given here. Richards and Tamaru [8] found that the temperature coefficient of the heat of solution of cadmium in concentrated $\mathrm{HCl}$ was $-71 \mathrm{cal} /{ }^{\circ} \mathrm{C}$ and believed that even for dilute acid it amounted to as much as $-30 \mathrm{cal} /{ }^{\circ} \mathrm{C}$. Since reaction (al) is for dilute

${ }^{6}$ Each equation was altered slightly to make it conform with the values in reference $[24]$ at $25^{\circ} \mathrm{C}$. acid $-30 \mathrm{cal} /{ }^{\circ} \mathrm{C}$ is taken for the temperature coefficient; owing to the estimation made by Richards and Tamaru a large uncertainty of $\pm 10 \mathrm{cal} /{ }^{\circ} \mathrm{C}$ is attributed to this value.

Thomsen [9] stated that the temperature of his observations for reactions (a2) and (a3) was $18-20^{\circ} \mathrm{C}$. A mean temperature of $19^{\circ} \mathrm{C}$ is taken here, and Thomsen's values were corrected to $18{ }^{\circ} \mathrm{C}$ using the known heat capacity of $\mathrm{BaSO}_{4}(\mathrm{~s})[10]$ as a function of temperature and the heat capacities of the $\mathrm{Ba}^{++}$and $\mathrm{SO}_{4}^{=}$ ions at $25^{\circ} \mathrm{C}$ given by Pitzer and Brewer [11] (these latter values were assumed to be temperature and concentration independent). Since the difference of (a2) and (a3) is taken in arriving at the value for the overall reaction, an error in this temperature correction is negligible.

The temperature correction for the sum of the reactions (a9), (a10), and (al1) was obtained from the known heat capacities of $\mathrm{Hg}_{2} \mathrm{SO}_{4}(\mathrm{~s})$ [14], $\mathrm{Hg}(\mathrm{l})$ [14], and $\mathrm{I}_{2}$ (s) [10] as functions of temperature and of $\mathrm{KI}, \mathrm{HgI}_{2}$, and $\mathrm{K}_{2} \mathrm{SO}_{4}$ as functions of concentration and temperature as follows. The heat capacity of $\mathrm{HgI}_{2}$ was taken equal to that of KI (since it was dissolved in KI solutions) and that of $\mathrm{K}_{2} \mathrm{SO}_{4}$ as equal to 0.917 times twice the heat capacity of $\mathrm{KOH}$ (the temperature coefficient for $\mathrm{K}_{2} \mathrm{SO}_{4}$ was taken equal to that for $\mathrm{KOH}$ ). The factor 0.917 is the ratio of the heat capacity of $2 \mathrm{KOH}$ and $\mathrm{K}_{2} \mathrm{SO}_{4}$ at infinite dilution; the value for $\mathrm{SO}_{4}^{=}$ was taken from the compilation of Pitzer and Brewer [11]. The heat capacities of aqueous solutions of KI and $\mathrm{KOH}$ at $25^{\circ} \mathrm{C}$, as a function of concentration, were taken from the compilation of Parker [15]. The temperature coefficient for $\mathrm{HCl}$ was used for the temperature coefficient of KI and the temperature coefficient of $\mathrm{NaOH}$ was used for the temperature coefficient for $\mathrm{KOH}[15]$. These values lead to:

$\Delta C_{p}$ [sum of reactions (a9), (al0), (al1)]

$$
=-579.9+2.14 T
$$


for the change in heat capacity for the sum of reactions (a9), (al0), and (al1). The estimated uncertainty for equation (19) is $\pm 10 \mathrm{cal} /{ }^{\circ} \mathrm{C}$.

The temperature correction for reaction (al4) was obtained using the known heat capacities of $I_{2}(\mathrm{~s})$ [10], $\mathrm{HCl}(\mathrm{g})$ [18], $\mathrm{HI}(\mathrm{g})$ [18], and $\mathrm{Cl}_{2}(\mathrm{~g})$ [10] as functions of temperature, or:

$$
\Delta C_{p}[\text { reaction }(\mathrm{al} 4)]=-0.84-0.0101 T-76000 / T^{2}
$$

An uncertainty of $\pm 10 \mathrm{cal} /{ }^{\circ} \mathrm{C}$ is assigned to this temperature correction.

Richards and Rowe [19] found an average of -50.9 $\mathrm{cal} /{ }^{\circ} \mathrm{C}$ for the temperature coefficient for the neutralization of $\mathrm{HCl}(100)$ and of $\mathrm{HNO}_{3}(100)$ with $\mathrm{LiOH}(100)$, $\mathrm{NaOH}(100)$, and $\mathrm{KOH}(100)$. This average temperature coefficient is assumed here to also apply to the neutralization of $\mathrm{KOH}(100)$ with $\mathrm{HI}(100)$ with an uncertainty of $\pm 9 \mathrm{cal} /{ }^{\circ} \mathrm{C}$, the spread found between the values found for the neutralization of $\mathrm{HCl}(100)$ and of $\mathrm{HNO}_{3}$ (100) with $\mathrm{KOH}(100)$.

Müller [20] measured the neutralization of $\mathrm{H}_{2} \mathrm{SO}_{4}$ (55.5) with potassium hydroxide of various dilutions (one mole of $\mathrm{KOH}$ in 13.508, 27.420, and 51.626 liters of water) at $17^{\circ} \mathrm{C}$. A value for the heat of neutralization of $\mathrm{H}_{2} \mathrm{SO}_{4}(55.5)$ with one mole of $\mathrm{KOH}$ in 2 liters of water was obtained by extrapolation of $\Delta H$ (neutralization) against $\sqrt{\text { volume; }} \Delta H$ (neutralization) versus $\sqrt{\text { volume }}$ is a straight line over the range of observations made by Müller. An uncertainty of $\pm 150 \mathrm{cal} /{ }^{\circ} \mathrm{C}$ per mole of $\mathrm{KOH}(111)$ is assigned to this heat of reaction owing to the spread in the three values obtained by Müller. This neutralization value is much higher than the older values of Thomsen [9] and Berthelot [25]. The older values were probably low because of the presence of carbonate in the alkali as has been shown for similar cases by Keyes, Gillespie, and Mitsukuri [26]. The value was corrected to $18{ }^{\circ} \mathrm{C}$, with an estimated additional uncertainty of $\pm 10 \mathrm{cal} /{ }^{\circ} \mathrm{C}$ using the known heat capacity of water $[14]^{7}$ as a function of temperature and of $\mathrm{H}_{2} \mathrm{SO}_{4} . \mathrm{KOH}$, and $\mathrm{K}_{2} \mathrm{SO}_{4}$ as functions of concentration and temperature using the procedure discussed above in obtaining the temperature coefficient for the sum of the reactions (a9), (al0), and (a11). These values lead to

$$
\Delta C_{p}[(\text { reaction }(\text { al9) }]=574.17-1.772 T
$$

for the change in heat capacity for reaction (a19).

For the reactions (al3) and (al4) the uncertainties given in the parentheses are the \pm uncertainties given by the experimenters. In the other cases the experimenters were not explicit on their experimental uncertainties. For (al), Richards and Tamaru [8] stated that the maximum uncertainty if all errors were additive, which would be highly unlikely, would be 70 $\mathrm{cal} \mathrm{mol}^{-1}$, and that the probable error was undoubtedly much less. Their maximum uncertainty is retained

${ }^{7}$ Equation given in reference [14] was altered slightly to make equation consistent with the $25^{\circ} \mathrm{C}$ value given in reference $[22]$. here and an additional uncertainty of $\pm 10 \mathrm{cal} /{ }^{\circ} \mathrm{C}$ is assigned to the temperature coefficient. The uncertainties assigned to (a2) and (a3) were deduced from the temperature correction, i.e., were taken as one half the correction. For (a7), Cohen, Helderman and Moesveld [7] made eight determinations of the heat evolved; the standard deviation of their mean value is $7 \mathrm{cal} \mathrm{mol}^{-1}$. The average spread in their values is taken, however, as the overall uncertainty. For (a10) Varet gave a general value which differs from that given above for (al0) by $400 \mathrm{cal} \mathrm{mol}^{-1}$; this is taken as the uncertainty and the same percentage uncertainty is assigned to (a9), a reaction also studied by Varet. For (al6) Richards and Rowe stated that the maximum uncertainty in their value was 0.07 percent, and is used here. The estimated uncertainty for (a19) was discussed above. The uncertainties for the other reactions, which are mostly ones for solution or dilution, are estimated ones.

The overall uncertainty value is obtained from the sum of the uncertainties for each reaction taking care of sign. An overall uncertainty may also be taken as the root sum square value of the uncertainties of the 21 reactions, namely $397 \mathrm{cal} \mathrm{mol}^{-1}$ or $1661 \mathrm{~J} \mathrm{~mol}^{-1}$ and is the second uncertainty given above. The actual uncertainty probably lies between these two estimates. A root mean square value of the uncertainty is $88 \mathrm{cal}$ $\mathrm{mol}^{-1}$ or $368 \mathrm{~J} \mathrm{~mol}^{-1}$; this value of the uncertainty is close to the first one listed above.

Values for the entropy of $\mathrm{Cd}(\mathrm{s}), \mathrm{Hg}_{2} \mathrm{SO}_{4}(\mathrm{~s}), \mathrm{CdSO}_{4}(\mathrm{~s})$, and $\mathrm{Hg}(\mathrm{l})$ at $25{ }^{\circ} \mathrm{C}$ are 12.37 [27], 47.96 [24], 29.41 [21], and 18.19 [27] cal $\mathrm{K}^{-1} \mathrm{~mol}^{-1}$, or $51.75,200.66$, 123.05 , and $76.02 \mathrm{~J} \mathrm{~K}^{-1} \mathrm{~mol}^{-1}$, respectively. Therefore, $\Delta S_{a}$ for reaction (a) is $5.42 \mathrm{cal} \mathrm{K}^{-1} \mathrm{~mol}^{-1}$ or 22.68 $\mathrm{J} \mathrm{K}^{-1} \mathrm{~mol}^{-1}$. This value combined with the value of $\Delta H_{a}$, given above, gives according to eq (1) $-47,023$ cal mol-1 or $-196,745 \mathrm{~J} \mathrm{~mol}^{-1}$ for the Gibbs energy (free energy) change, $\Delta G_{a}$, for reaction (a). Since $\Delta G=-n E F$ [see eq (4)] $E$ would be $1.0195396 \mathrm{~V}$ at $25{ }^{\circ} \mathrm{C}$ for the standard cell of the saturated cadmium sulfate type, if the cell reaction were as depicted by reaction (a). Also, since $\Delta S=n F(d E / d T)$ [see eq (6)], $d E / d T$ for the cell at $25^{\circ} \mathrm{C}$ would be $0.00011751 \mathrm{~V} /{ }^{\circ} \mathrm{C}$, if the cell reaction were as depicted by reaction (a). Since these values do not agree with the observed ones (see later) it follows that the cell reaction does not correspond to reaction (a).

The heat capacities at $25{ }^{\circ} \mathrm{C}$ of $\mathrm{Cd}(\mathrm{s}), \mathrm{Hg}_{2} \mathrm{SO}_{4}(\mathrm{~s})$, $\mathrm{CdSO}_{4}(\mathrm{~s})$, and $\mathrm{Hg}(\mathrm{l})$ are, respectively, 6.21 [24], 31.54 [24], 23.806 [24], and 6.688 [24] $\mathrm{cal} \mathrm{K}^{-1} \mathrm{~mol}^{-1}$ or 25.90, $132.00,99.62$, and $27.82 \mathrm{~J} \mathrm{~K}^{-1} \mathrm{~mol}^{-1} ; \Delta C_{p}$ is therefore, $-0.580 \mathrm{cal} \mathrm{K}^{-1} \mathrm{~mol}^{-1}$ or $-2.427 \mathrm{~J} \mathrm{~K}^{-1} \mathrm{~mol}^{-1}$. Stull and Sinke [27] give $6.19 \mathrm{cal} \mathrm{K}^{-1} \mathrm{~mol}^{-1}$ for $\mathrm{Cd}(\mathrm{s})$. Papadopoulos and Giauque [21] give $23.806 \mathrm{cal} \mathrm{K}^{-1}$ $\mathrm{mol}^{-1}$ for $\mathrm{CdSO}_{4}(\mathrm{~s})$, and Giauque, Barieau and Kunzler [14] give 31.689 and $6.702 \mathrm{cal} \mathrm{K}^{-1} \mathrm{~mol}^{-1}$ for $\mathrm{Hg}_{2} \mathrm{SO}_{4}(\mathrm{~s})$ and $\mathrm{Hg}(1)$, respectively. These values yield -0.669 cal K $\mathrm{Kol}^{-1}$ or $-2.799 \mathrm{~J} \mathrm{~K}^{-1} \mathrm{~mol}^{-1}$ for $\Delta C_{p}$ (a).

\section{Reaction (b)} by:

The Gibbs energy change for reaction (b) is given 


$$
\begin{aligned}
\Delta G_{b}=R T \ln \frac{p^{*}}{p^{0}}=R T \ln \frac{0.62}{23.7667} \\
\quad=-2160 \mathrm{cal} \mathrm{mol}^{-1}=-9037 \mathrm{~J} \mathrm{~mol}^{-1}
\end{aligned}
$$

where $p^{0}$ is the vapor pressure of water at $25{ }^{\circ} \mathrm{C}$ [28], $p^{*}$ the vapor pressure of the system $\mathrm{CdSO}_{4}$. $\mathrm{H}_{2} \mathrm{O}-\mathrm{H}_{2} \mathrm{O}, T$ the Kelvin temperature, and $R$ the gas constant $\left(1.98717 \mathrm{cal} \mathrm{K}^{-1} \mathrm{~mol}^{-1}\right.$ or $8.3143 \mathrm{~J} \mathrm{~K}^{-1} \mathrm{~mol}^{-1}$ [1]). Ishikawa and Murooka [29] obtained $0.62 \mathrm{~mm}$ $\mathrm{Hg}$ for $p^{*}$. The values in $\mathrm{mm} \mathrm{Hg}$ may be converted to pascals by the relation $1 \mathrm{~mm} \mathrm{Hg}\left(0^{\circ} \mathrm{C}\right)=1.333224$ $\times 10^{2}$ pascals.

The entropies for $\mathrm{CdSO}_{4}(\mathrm{~s}), \mathrm{H}_{2} \mathrm{O}(\mathrm{l})$, and $\mathrm{CdSO}_{4}$. $\mathrm{H}_{2} \mathrm{O}(\mathrm{s})$ at $25{ }^{\circ} \mathrm{C}$ are, respectively, 29.41 [21], 16.71 [24], and 36.82 [21] cal $\mathrm{K}^{-1} \mathrm{~mol}^{-1}$ or $123.05,69.91$, $154.05 \mathrm{~J} \mathrm{~K}^{-1} \mathrm{~mol}^{-1}$; therefore, $\Delta S_{b}$ for reaction (b) is $-9.30 \mathrm{cal} \mathrm{K}^{-1} \mathrm{~mol}^{-1}$ or $-38.91 \mathrm{~J} \mathrm{~K}^{-1} \mathrm{~mol}^{-1}$. This value combined with the value for $\Delta G_{b}$ above gives by eq (1) $-4,933 \mathrm{cal} \mathrm{mol}^{-1}$ or $-20,640 \mathrm{~J} \mathrm{~mol}^{-1}$ for $\Delta H_{b}$, the heat of reaction for reaction (b). Papadopoulos and Giauque [21] measured the heats of solution of $\mathrm{CdSO}_{4}(\mathrm{~s})$ and $\mathrm{CdSO}_{4} \cdot \mathrm{H}_{2} \mathrm{O}(\mathrm{s})$ in 400 moles of water at $25{ }^{\circ} \mathrm{C}$ for which thev obtained $-10,977$ and -6095 cal $\mathrm{mol}^{-1}$ or $-45,928$ and $-25,501 \mathrm{~J} \mathrm{~mol}^{-1}$, respectively. These yield $-4,882 \mathrm{cal} \mathrm{mol}^{-1}$ or $-20,426 \mathrm{~J}$ $\mathrm{mol}^{-1}$ for $\Delta H_{b}$ which differs by $51 \mathrm{cal} \mathrm{mol}^{-1}$ or $214 \mathrm{~J}$ $\mathrm{mol}^{-1}$ from that calculated above.

The heat capacities of $\mathrm{CdSO}_{4}(\mathrm{~s}), \mathrm{H}_{2} \mathrm{O}(\mathrm{l})$, and $\mathrm{CdSO}_{4} \cdot \mathrm{H}_{2} \mathrm{O}(\mathrm{s})$ at $25{ }^{\circ} \mathrm{C}$ are, respectively, 23.806 [21], 17.995 [30], and 32.157 [21] $\mathrm{cal} \mathrm{K}^{-1} \mathrm{~mol}^{-1}$ or 99.58, 75.29 , and 134.544 $\mathrm{J} \mathrm{K}^{-1} \mathrm{~mol}^{-1}$; therefore, $\Delta C_{p(\mathrm{~b})}$ for reaction (b) is $-9.644 \mathrm{cal} \mathrm{K}^{-1} \mathrm{~mol}^{-1}$ or -40.350 $\mathrm{J} \mathrm{K}^{-1} \mathrm{~mol}^{-1}$.

\section{Reaction (c)}

The Gibbs energy change for reaction (c) is given by:

$$
\begin{aligned}
\Delta G_{c}=\frac{5}{3} R T \ln \frac{p^{* *}}{p^{0}}=\frac{5}{3} R T & \ln \frac{17.4}{23.7667} \\
& =-308 \mathrm{cal}=-1289 \mathrm{~J}
\end{aligned}
$$

where $p^{* *}$ is the vapor pressure of the system $\mathrm{CdSO}_{4} \cdot \frac{8}{3} \mathrm{H}_{2} \mathrm{O}-\mathrm{CdSO}_{4} \cdot \mathrm{H}_{2} \mathrm{O}$ and $p^{0}, T$, and $R$ have the same significance as given above. The average of the results of Ishikawa and Murooka [29] and of Carpenter and Jette [31] gives $17.4 \mathrm{~mm} \mathrm{Hg}$ for $p^{* *}$. Conversion to pascals may be done as stated above.

The entropies for $\mathrm{CdSO}_{4} \cdot \mathrm{H}_{2} \mathrm{O}(\mathrm{s})$ and $\mathrm{H}_{2} \mathrm{O}(\mathrm{l})$ have been given above. The entropy of $\mathrm{CdSO}_{4} \cdot \frac{8}{3} \mathrm{H}_{2} \mathrm{O}(\mathrm{s})$ is $54.89[21] \mathrm{cal} \mathrm{K}^{-1} \mathrm{~mol}^{-1}$ or $229.66 \mathrm{~J} \mathrm{~K}^{-1} \mathrm{~mol}^{-1} . \Delta S_{c}$ is, therefore, $-9.78 \mathrm{cal} \mathrm{K}^{-1} \mathrm{~mol}^{-1}$ or $-40.92 \mathrm{~J} \mathrm{~K}^{-1}$ $\mathrm{mol}^{-1}$. This value combined with the value for $\Delta G_{c}$ given above gives by eq $(1)-3,224 \mathrm{cal}$ or $-13,489 \mathrm{~J}$ for $\Delta H_{c}$, the heat of reaction for reaction (c). Papadopoulos and Giauque [21] measured the heats of solution of $\mathrm{CdSO}_{4} \cdot \mathrm{H}_{2} \mathrm{O}(\mathrm{s})$ and $\mathrm{CdSO}_{4} \cdot \frac{8}{3} \mathrm{H}_{2} \mathrm{O}(\mathrm{s})$ in 400 moles of water at $25{ }^{\circ} \mathrm{C}$ for which they obtained $-6,095$ and
$-2,899 \mathrm{cal} \mathrm{mol}^{-1}$ or $-25,502$ and $-12,129 \mathrm{~J} \mathrm{~mol}^{-1}$, respectively. These yield $-3,196 \mathrm{cal} \mathrm{mol}^{-1}$ or $-13,372$ $\mathrm{J} \mathrm{mol}^{-1}$ for $\Delta H_{c}$ which differs by $28 \mathrm{cal} \mathrm{mol}^{-1}$ or 117 $\mathrm{J} \mathrm{mol}^{-1}$ from that calculated above.

The heat capacities of $\mathrm{CdSO}_{4} \cdot \mathrm{H}_{2} \mathrm{O}(\mathrm{s})$ and $\mathrm{H}_{2} \mathrm{O}(\mathrm{l})$ have been given above. The heat capacity of $\mathrm{CdSO}_{4} \cdot \frac{8}{3} \mathrm{H}_{2} \mathrm{O}(\mathrm{s})$ at $25{ }^{\circ} \mathrm{C}$ is $50.972 \mathrm{cal} \mathrm{K}^{-1} \mathrm{~mol}^{-1}$ [21] or $213.26 \mathrm{~J} \mathrm{~K}^{-1} \mathrm{~mol}^{-1}$. Therefore, $\Delta C_{p(\mathrm{c})}$ for reaction (c) is $-11.177 \mathrm{cal}$ or $-46.765 \mathrm{~J}$.

\section{Reaction (d)}

The Gibbs energy change for reaction (d) is given by:

$$
\Delta G_{d}=\frac{8}{3} R T \ln \frac{p^{0}}{p^{s}}=\frac{8}{3} R T \ln \frac{23.7667}{21.17}=184 \mathrm{cal}=770 \mathrm{~J}
$$

where $p^{s}$ is the vapor pressure of a saturated solution of $\mathrm{CdSO}_{4} \cdot \frac{8}{3} \mathrm{H}_{2} \mathrm{O}$ and $p^{0}, T$, and $R$ have the significance given above. Ishikawa and Murooka [29] obtained $21.17 \mathrm{~mm} \mathrm{Hg}$ for the vapor pressure of the saturated solution at $25{ }^{\circ} \mathrm{C}$; this value may be converted to pascals as described above. Holsboer [32] found that 1,044 calories or 4,368 joules of heat were evolved when one mole of $\mathrm{CdSO}_{4} \cdot \frac{8}{3} \mathrm{H}_{2} \mathrm{O}(\mathrm{s})$ was dissolved in enough water to form the saturated solution at $25^{\circ} \mathrm{C}$; for $(8 / 3) /(m-8 / 3)$ mole of salt the heat evolved would be $224 \mathrm{cal}$ or $938 \mathrm{~J}$ since $m=15.089[5,6]$ at $25^{\circ} \mathrm{C}$ and $(8 / 3) /(m-8 / 3)=0.2147$. Combining these values for $\Delta G_{d}$ and $\Delta H_{d}$ gives 0.13 cal $\mathrm{K}^{-1}$ or $0.544 \mathrm{~J} \mathrm{~K}^{-1}$ for $\Delta S_{d}$, the entropy change for reaction (d).

Cohen and Moesveld [33] obtained $0.5836 \mathrm{cal} \mathrm{g}^{-1}$ or $2.4414 \mathrm{~J} \mathrm{~g}^{-1}$ for the specific heat of a saturated solution of $\mathrm{CdSO}_{4} \cdot \frac{8}{3} \mathrm{H}_{2} \mathrm{O}$ at $19{ }^{\circ} \mathrm{C}$ which becomes $0.5823 \mathrm{cal}$ $\mathrm{g}^{-1}$ or $2.4359 \mathrm{~J} \mathrm{~g}^{-1}$ at $25{ }^{\circ} \mathrm{C}$ based on the higher concentration of the saturated solution at $25{ }^{\circ} \mathrm{C}$ and the ratio of the specific heat of water at 25 and $19{ }^{\circ} \mathrm{C}$. Accordingly $(8 / 3) /(m-8 / 3)$ mole of a saturated solution of $\mathrm{CdSO}_{4} \cdot \frac{8}{3} \mathrm{H}_{2} \mathrm{O}$ has a heat capacity of $59.93 \mathrm{cal} \mathrm{K}^{-1}$ or $250.705 \mathrm{~J} \mathrm{~K}^{-1}$ at $25^{\circ} \mathrm{C}$; on the present thermochemical calorie the value is $59.92 \mathrm{cal} \mathrm{K}^{-1}$ or $250.706 \mathrm{~J} \mathrm{~K}^{-1}$. Combining this value with the heat capacity of $\mathrm{H}_{2} \mathrm{O}(\mathrm{l})$ and $\mathrm{CdSO}_{4} \cdot \frac{8}{3} \mathrm{H}_{2} \mathrm{O}(\mathrm{s})$, given above, gives -0.999 cal $\mathrm{K}^{-1}$ or $-4.180 \mathrm{~J} \mathrm{~K}^{-1}$ for $\Delta C_{p(\mathrm{~d})}$ for reaction (d).

The above values are summarized in tables 1 and 2 ; data are given in SI units in the first section of each table and in defined calories in the second section. Table 1 is based on experimental values for the Gibbs energy changes for reactions (b), (c), and (d) and the enthalpy changes for reactions (a) and (d). Table 2 is based on experimental values for the Gibbs energy change of reaction (d) and the enthalpy changes of reactions (a), (b), (c), and (d). The addition of these values for reactions (a), (b), (c), and (d) gives sum 1 or the values for the reaction in a standard cell of the 
TABLE 1. Thermodynamic data for the reaction in standard cells of the saturated cadmium sulfate type at $25{ }^{\circ} \mathrm{C}$-based on experimental Gibbs energies for reactions (b), (c), and (d) and experimental enthalpies for reactions $(a)$ and $(d)$

\begin{tabular}{|c|c|c|c|c|}
\hline \multirow{2}{*}{ Reaction } & $\begin{array}{l}\text { Gibbs } \\
\text { energy } \\
\text { change }\end{array}$ & $\begin{array}{l}\text { Enthalpy } \\
\text { change }\end{array}$ & $\begin{array}{l}\text { Entropy } \\
\text { change }\end{array}$ & $\begin{array}{l}\text { Heat- } \\
\text { capacity } \\
\text { change }\end{array}$ \\
\hline & $\begin{array}{c}\Delta G \\
\mathrm{~J} \mathrm{~mol}^{-1}\end{array}$ & $\begin{array}{c}\Delta H \\
\mathrm{~J} \mathrm{~mol}^{-1}\end{array}$ & $\begin{array}{c}\Delta S \\
\mathrm{~J} \mathrm{~K}^{-1} \mathrm{~mol}^{-1}\end{array}$ & $\begin{array}{c}\Delta C_{p} \\
\mathrm{~J} \mathrm{~K}^{-1} \mathrm{~mol}^{-1}\end{array}$ \\
\hline (d) & $\begin{array}{r}\#(-196,745) \\
-9,037 \\
-1,289 \\
770\end{array}$ & $\begin{array}{c}-189,983 \\
(-20,640) \\
(-13,489) \\
937\end{array}$ & $\begin{array}{c}22.68 \\
-38.91 \\
-40.92 \\
(0.544)\end{array}$ & $\begin{array}{r}\phi-2.427 \\
-40.350 \\
-46.765 \\
-4.180\end{array}$ \\
\hline $\begin{array}{l}\operatorname{sum}_{(\mathrm{e})^{*}} 1 \ldots \\
\ldots\end{array}$ & $\begin{array}{r}-206,301 \\
9,743\end{array}$ & $\begin{array}{r}-223,175 \\
23,764\end{array}$ & $\begin{array}{c}-56,606 \\
47.03\end{array}$ & $\begin{array}{c}-93.722 \\
0\end{array}$ \\
\hline $\begin{array}{l}\operatorname{sum} 2^{p} \ldots \ldots \\
(\mathrm{e})^{* *} \ldots \ldots \ldots\end{array}$ & $\begin{array}{r}-196,558 \\
9,738\end{array}$ & $\begin{array}{r}-199,411 \\
21,240\end{array}$ & $\begin{array}{c}-9.576 \\
38.58\end{array}$ & $\begin{array}{c}-93.722 \\
204.26\end{array}$ \\
\hline \multirow[t]{2}{*}{$\operatorname{sum} 3^{q} \ldots \ldots$} & $-196,563$ & $-201,935$ & -18.026 & 110.538 \\
\hline & $\left(\text { cal mol }{ }^{-1}\right)^{j}$ & cal mol-1 & $\begin{array}{c}\mathrm{cal} \mathrm{K}^{-1} \\
\mathrm{~mol}^{-1}\end{array}$ & $\begin{array}{c}\text { cal K } \\
\mathrm{mol}^{-1}\end{array}$ \\
\hline $\begin{array}{l}\text { (c) } \ldots \ldots \ldots \\
\text { (d) } \ldots \ldots\end{array}$ & $\begin{array}{r}(-47,023) \\
-2,160 \\
-308 \\
184\end{array}$ & $\begin{array}{c}-45,407 \\
(-4,933) \\
(-3,224) \\
224\end{array}$ & $\begin{array}{r}5.42 \\
-9.30 \\
-9.78 \\
(0.13)\end{array}$ & $\begin{array}{r}\phi-0.580 \\
-9.644 \\
-11.177 \\
-0.999\end{array}$ \\
\hline $\begin{array}{l}\operatorname{sum} 1 \ldots \ldots \\
(\mathrm{e})^{*} \ldots \ldots \ldots\end{array}$ & $\begin{array}{r}-49,307 \\
2,328.6\end{array}$ & $\begin{array}{r}-53,340 \\
5,679.8\end{array}$ & $\begin{array}{r}-13.53 \\
11.24\end{array}$ & $\begin{array}{l}-22.400 \\
0\end{array}$ \\
\hline $\begin{array}{l}\operatorname{sum} 2^{p} \ldots \\
(\mathrm{e})^{* *} \ldots \ldots\end{array}$ & $\begin{array}{r}-46,978.4 \\
2,327.5\end{array}$ & $\begin{array}{r}-47,660.2 \\
5,076.4\end{array}$ & $\begin{array}{r}-2.29 \\
9.22\end{array}$ & $\begin{array}{c}-22.400 \\
48.82\end{array}$ \\
\hline sum & $-46,979.5$ & $-48,263.6$ & -4.31 & 26.420 \\
\hline
\end{tabular}

\# Values in parentheses were calculated from the relation $\Delta G=\Delta H-T \Delta S$.

$\phi$ See text for alternate value of $-2.799 \mathrm{~J} \mathrm{~K}^{-1} \mathrm{~mol}^{-1}$ or -0.669 cal K $\mathrm{K}^{-1} \mathrm{~mol}^{-1}$.

* Based on data of Hulett [34] and Getman [35].

$p$ Sum $1+(\mathbf{e})^{*}$.

** Based on data of Parks and LaMer [39].

$q \quad$ Sum $1+(\mathrm{e})^{* *}$.

$j \quad 1$ Thermochemical calorie $($ defined $)=4.184 \mathrm{~J}[1]$.

saturated cadmium sulfate type at $25^{\circ} \mathrm{C}$ if the anode were made of cadmium metal rather than cadmium amalgam.

\section{Reaction (e)}

Calorimetric and chemical equilibrium measurements on reaction (e) have not been made. It is necessary, therefore, to rely on electrochemical measurements for information on reaction (e). Hulett [34] and Getman [35] measured the emf of the cell:

\section{$(-) \mathrm{Cd}($ metal $) \mid \mathrm{CdSO}_{4}($ sol $) \mid \mathrm{Cd}$ amalgam (8-10\%)(+)}

at a series of temperatures and obtained:

$$
E(\text { in volts })=0.050487-0.0002437\left(t-25^{\circ} \mathrm{C}\right)
$$

for the emf as a function of temperature. In cell (A) sol denotes an aqueous solution. Sir Frank Smith [36] showed that 8-percent and 10-percent amalgams have
TABLE 2. Thermodynamic data for the reaction in standard cells of the saturated cadmium sulfate type at $25{ }^{\circ} \mathrm{C}$-based on experimental enthalpies for reactions $(a),(b),(c)$, and $(d)$ and experimental Gibbs energy for reaction $(d)$

\begin{tabular}{|c|c|c|c|c|}
\hline \multirow[t]{2}{*}{ Reaction } & $\begin{array}{l}\text { Gibbs } \\
\text { energy } \\
\text { change }\end{array}$ & $\begin{array}{l}\text { Enthalpy } \\
\text { change }\end{array}$ & $\begin{array}{l}\text { Entropy } \\
\text { change }\end{array}$ & $\begin{array}{l}\text { Heat- } \\
\text { capacity } \\
\text { change }\end{array}$ \\
\hline & $\underset{\mathrm{J} \mathrm{mol}^{-1}}{\Delta G}$ & $\begin{array}{c}\Delta H \\
\mathrm{~J} \mathrm{~mol}^{-1}\end{array}$ & $\begin{array}{c}\Delta S \\
\mathrm{~J} \mathrm{~K}^{-1} \mathrm{~mol}^{-1}\end{array}$ & $\underset{\mathrm{J} \mathrm{K}}{\Delta C_{p}^{-1} \mathrm{~mol}^{-1}}$ \\
\hline $\begin{array}{l}\text { (a).. } \\
\text { (b).. } \\
\text { (c).. } \\
\text { (d).. }\end{array}$ & $\begin{array}{r}\#(-196,745) \\
(-8,824) \\
(-1,171) \\
770\end{array}$ & $\begin{array}{r}-189,983 \\
-20,426 \\
-13,372 \\
937\end{array}$ & $\begin{aligned} & 22.68 \\
&- 38.91 \\
&- 40.92 \\
&(0.544)\end{aligned}$ & $\begin{array}{r}\phi-2.402 \\
-40.350 \\
-46.765 \\
-4.180\end{array}$ \\
\hline $\begin{array}{l}\operatorname{sum} 1 \ldots \ldots \ldots \\
(\mathrm{e})^{*} \ldots \ldots \ldots\end{array}$ & $\begin{array}{r}-205,970 \\
9,743\end{array}$ & $\begin{array}{r}-222,844 \\
23,764\end{array}$ & $\begin{array}{c}-56.606 \\
47.03\end{array}$ & $\begin{array}{c}-93.722 \\
0\end{array}$ \\
\hline $\begin{array}{l}\operatorname{sum}_{(\mathrm{e})^{* *}} 2^{p} \ldots \ldots \ldots \\
\end{array}$ & $\begin{array}{r}-196,227 \\
9,738\end{array}$ & $\begin{array}{r}-199,080 \\
21,240\end{array}$ & $\begin{array}{c}-9.576 \\
38.58\end{array}$ & $\begin{array}{c}-93.722 \\
204.26\end{array}$ \\
\hline \multirow[t]{2}{*}{$\operatorname{sum} 3^{q} \ldots \ldots$} & $-196,232$ & $-201,604$ & -18.026 & 110.538 \\
\hline & $\left(\mathrm{cal} \mathrm{mol}{ }^{-1}\right)^{j}$ & cal mol-1 & $\begin{array}{l}\text { cal K-1 } \\
\text { mol }^{-1}\end{array}$ & $\begin{array}{c}\mathrm{cal} \mathrm{K}^{-1} \\
\mathrm{~mol}^{-1}\end{array}$ \\
\hline $\begin{array}{l}\text { (a) } \ldots \ldots \\
\text { (b) } \ldots \ldots \\
\text { (c) } \ldots \ldots \\
\text { (d) } \ldots \ldots \\
\end{array}$ & $\begin{array}{r}(-47,023) \\
(-2,109) \\
-280 \\
184\end{array}$ & $\begin{array}{r}-45,407 \\
-4,882 \\
-3,196 \\
224\end{array}$ & $\begin{array}{r}5.42 \\
-9.30 \\
-9.78 \\
(0.13)\end{array}$ & $\begin{array}{r}\phi-0.580 \\
-9.644 \\
-11.177 \\
-0.999\end{array}$ \\
\hline $\begin{array}{l}\operatorname{sum} 1 \ldots \ldots \ldots \\
(\mathrm{e})^{*} \ldots \ldots \ldots \ldots\end{array}$ & $\begin{array}{r}-49,228 \\
2,328.6 \\
\end{array}$ & $\begin{array}{r}-53,261 \\
5,679.8 \\
\end{array}$ & $\begin{array}{r}-13.53 \\
11.24 \\
\end{array}$ & $\begin{array}{c}-22.400 \\
0\end{array}$ \\
\hline $\begin{array}{l}\operatorname{sum} 2^{p} \ldots \ldots \\
(\mathrm{e})^{* *} \ldots \ldots \ldots\end{array}$ & $\begin{array}{r}-46,899.4 \\
2,327.5\end{array}$ & $\begin{array}{r}-47.581 .2 \\
5.076 .4\end{array}$ & $\begin{array}{r}-2.29 \\
9.22\end{array}$ & $\begin{array}{c}-22.400 \\
48.82\end{array}$ \\
\hline sum 3 & $-46,900.5$ & $-48,184.6$ & -4.31 & 26.420 \\
\hline
\end{tabular}

\#Values in parentheses were calculated from the relation $\Delta G=\Delta H-T \Delta S$.

$\phi$ See text for alternate value of $-2.799 \mathrm{~J} \mathrm{~K}^{-1} \mathrm{~mol}^{-1}$ or -0.669 cal K ${ }^{-1} \mathrm{~mol}^{-1}$.

* Based on data of Hulett [34] and Getman [35].

p Sum $1+(\mathrm{e})^{*}$.

** Based on data of Parks and LaMer [39].

$q \quad$ Sum $1+(\mathbf{e})^{* *}$.

$j \quad 1$ Thermochemical calorie $($ defined $)=4.184 \mathrm{~J}[1]$.

the same electrical potential. Hulett and Getman's emfs, expressed in international volts were converted to absolute volts here using the relation: 1 international volt $(\mathrm{USA})=1.0003384$ absolute volts $[37,38]$. Their results give 2,328.6 $\mathrm{cal} \mathrm{mol}^{-1}, 5,679.8 \mathrm{cal} \mathrm{mol}^{-1}$, $11.24 \mathrm{cal} \mathrm{K}^{-1} \mathrm{~mol}^{-1}$, and 0 cal K${ }^{-1} \mathrm{~mol}^{-1}$ or $9,742.9 \mathrm{~J}$ $\mathrm{mol}^{-1}, 23,764.2 \mathrm{~J} \mathrm{~mol}^{-1}$, 47.03 J K-1 $\mathrm{mol}^{-1}$, and $0 \mathrm{~J} \mathrm{~K}^{-1}$ mol $^{-1}$ for $\Delta G_{e}, \Delta H_{e}, \Delta S_{e}$, and $\Delta C_{p(\mathrm{e})}$, respectively, for reaction $(\mathrm{e})$. (Note that reaction (e) is for the reverse reaction of the above cell.) These values are added to sum 1 in tables 1 and 2 to give sum 2 for the thermodynamic data for the reaction at $25{ }^{\circ} \mathrm{C}$ in standard cells of the saturated cadmium sulfate type.

Parks and LaMer [39] also measured the emf of the above cell (A) over the temperature range of 0 to $40^{\circ} \mathrm{C}$. They expressed their results by the equation:

$E$ (in volts $)=0.055399-0.000148 t-0.00000385 t^{2}$ $+0.000000075 t^{3}$.

Their emfs, given in international volts were converted 
here to absolute volts using the relation given directly above. Their results lead to $2,327.5 \mathrm{cal} \mathrm{mol}^{-1}, 5.076 .4$ cal mol-1, 9,22 $\mathrm{cal} \mathrm{K}^{-1} \mathrm{~mol}^{-1}$, and $48.82 \mathrm{cal} \mathrm{K}^{-1} \mathrm{~mol}^{-1}$ or $9,738.3 \mathrm{~J} \mathrm{~mol}^{-1}, 21,239.6 \mathrm{~J} \mathrm{~mol}, 38.58 \mathrm{~J} \mathrm{~K}^{-1} \mathrm{~mol}^{-1}$, and $204.26 \mathrm{~J} \mathrm{~K}^{-1} \mathrm{~mol}^{-1}$ for $\Delta G_{e}, \Delta H_{e}, \Delta S_{e}$, and $\Delta C_{p(\rho)}$, respectively, for reaction (e) at $25^{\circ} \mathrm{C}$. The value for $\Delta G_{e}$ agrees well with that obtained from Hulett and Getman's data but the values for the other thermodynamic functions do not. These differences are discussed in more detail later. These values are added to sum 1 in tables 1 and 2 give sum 3 for alternate thermodynamic data for the reaction at $25{ }^{\circ} \mathrm{C}$ in standard cells of the saturated cadmium sulfate type.

\section{Electromotive Force and Emf-temperature Coefficient}

The electromotive force of the so-called "neutral" or Normal standard cell was initially determined at $20{ }^{\circ} \mathrm{C}$ in terms of the international ohm and the international ampere by an International Committee on Electrical Units and Standards which met at the National Bureau of Standards in $1910 .^{8}$ As a result of numerous experiments they arrived at a value of 1.0183 $\mathrm{V}$ for the emf of the cell at $20^{\circ} \mathrm{C}$; values derived from this were later assumed to be significant to the fifth, sixth, or seventh decimal as a basis of measurement [5] and subsequent "absolute" measurements of the ohm and ampere confirmed the validity of this process. Somewhat earlier [42, 43, 44] Wolff investigated extensively the emf-temperature coefficient of the "neutral" type of standard cell made with $12 \frac{1}{2}$-percent cadmium amalgams. Wolff based his emf-temperature formula (or equation) on the results obtained from 0 to $40^{\circ} \mathrm{C}$, inclusive, on 137 cells, made in various ways, after rejecting the results on 63 cells for a variety of reasons, including cell leakage, abnormal initial emfs, excessive emf-temperature hysteresis, erratic behavior, or chemical instability. Wolff [42] first arrived at the approximate emf-temperature formula:

$$
\begin{aligned}
\mathrm{E}_{t} & =E_{20}{ }^{\circ} \mathrm{C}-0.0000406(t-20) \\
& -0.000000939(t-20)^{2}+0.000000009(t-20)^{3}
\end{aligned}
$$

by the method of least squares on the means of all observations on ten cells selected on the basis of their fast attainment of equilibrium after temperature changes. Using this approximate equation he then determined the residuals for all of the 137 cells at each temperature and calculated the corrections needed for the coefficients in eq (27) above. In this way he arrived at the emf-temperature formula:

$$
\begin{aligned}
E_{t} & =E_{20}{ }^{\circ} \mathrm{C}-0.00004064(t-20) \\
& -0.000000942(t-20)^{2}+0.0000000096(t-20)^{3}
\end{aligned}
$$

The 137 cells used to obtain eq (28) consisted of seven different groups of cells, namely, (1) 11 cells

* Some measurements on the emf of standard cells were made earlier (see reference $[5,40]$, and [41]) but these were not standardized internationally in terms of the mechanical units. The term "neutral" cell refers to one in which sulfuric acid. in low concentrations. is not intentionally added to the cell: actually, cadmium sulfate hydrolyzes to give sulfuric acid of $0.00092 N[5]$. made with electrolytic mercurous sulfate prepared at low current densities [45], (2) 53 cells made with electrolytic mercurous sulfate prepared at higher current densities [46], (3) 22 cells made with mercurous sulfate prepared chemically in different ways, (4) 19 cells made with various samples of commercial mercurous sulfate, (5) 13 cells made with exchange (gift) samples of electrolytic mercurous sulfate, (6) nine exchange cells (foreign and domestic), and (7) 10 cells made with high current-density electrolytic mercurous sulfate but with different samples of cadmium sulfate synthesized or treated in various ways. Except for group (7) the cadmium sulfate was commercial grade which was recrystallized several times from distilled water.

Wolff [43] later gave a different formula wherein the first, second, and third coefficients in eq (27) or (28) were, respectively, $0.00004075,-0.000000944$, and 0.0000000098 (these were uncorrected for residuals, compare data in references [42] and [43]).

The International Conference on Electrical Units and Standards meeting in London in 1908 adopted the formula (since known as the International formula) [47]:

$$
\begin{aligned}
E_{t}= & E_{20{ }^{\circ} \mathrm{C}}-0.0000406(t-20) \\
& -0.00000095(t-20)^{2}+0.00000001(t-20)^{3}
\end{aligned}
$$

giving weight to Wolff's original (provisional) emftemperature formula, eq (27) above. It should be noted that practically the same result follows if the data obtained on groups (4) and (6), for which the cells were not well characterized, and on those cells for which the emf-temperature coefficient at $20^{\circ} \mathrm{C}$ exceeds one microvolt are eliminated; these eliminations leave 99 cells for evaluation. Using these 99 cells gives:

$$
\begin{aligned}
E_{t} & =E_{20}{ }^{\circ} \mathrm{C}-0.00004049(t-20) \\
& -0.000000951(t-20)^{2}+0.00000000962(t-20)^{3}
\end{aligned}
$$

Equation (29), the International Temperature Formula, has been confirmed within the experimental uncertainty many times in succeeding years [48-53] for temperatures from 15 to $40^{\circ} \mathrm{C}$. The limits of uncertainty in the equation are discussed later.

Equations (29) and (30) may be given in the alternate forms:

$$
E=E_{0}{ }^{\circ} \mathrm{C}+0.0000094 t-0.00000155 t^{2}+0.00000001 t^{3}
$$

$$
\begin{aligned}
E=E_{0}{ }^{\circ} \mathrm{C} & +0.000009094 t-0.0000015282 t^{2} \\
& +0.00000000962 t^{3} . !(32)
\end{aligned}
$$

Vigoureux and Watts [54], Obata and Ishibashi [55], and Ishibashi and Ishizaki [50] also measured the emf-temperature coefficient of standard cells of the saturated cadmium sulfate type. However, their cells were of the "acid" type. i.e., sulfuric acid was added to the cell in small amounts $(0.1 N$ for ref. [54] and various amounts for ref. [55] and ref. [50]) and will, therefore, not be considered here. Furthermore, Vigoureux and Watts gave emphasis to measurements below $0{ }^{\circ} \mathrm{C}$. 
Obata and Ishibashi made measurements only from 15.6 to $29.6{ }^{\circ} \mathrm{C}$, and Ishibashi and Ishizaki from 15 to $30^{\circ} \mathrm{C}$.

The results of Wolff were expressed in international volts and on the temperature scale based on the constant-volume hydrogen gas thermometer, defined in terms of melting ice $\left(0^{\circ} \mathrm{C}\right)$ and boiling water $\left(100{ }^{\circ} \mathrm{C}\right)$, the hydrogen being taken at an initial manometric pressure of one meter of mercury; realization of the temperature scale was effected through mercurial thermometers calibrated in terms of the gas thermometer [56]. This temperature scale was the same as that adopted as the International Temperature Scale of 1927 [57].

On January 1, 1948 the international volt was replaced by the absolute volt; the change [37] for the United States was 1 international volt $(\mathrm{USA})=1.000330$ absolute volts. Then on January 1, 1969 another change [38] was made; the factor was: 1 USA volt ${ }_{48}=1.0000084$ USA volt 69 . Accordingly, the total change in going from the old international volt (USA) to the modern absolute volt is: 1 international volt $($ USA $)=1.0003384$ absolute USA volt 69 . In 1948 the International Temperature Scale was revised [57] but differed from the 1927 scale only at temperatures above $630{ }^{\circ} \mathrm{C}$ and, therefore, out of the, range of work done on standard cells by Wolff. However, in 1968 another revision of the International Temperature Scale was made [58] which did affect the precise value of the emf-temperature coefficient of standard cells; for example, $t_{68}-t_{48}$ is $-0.004{ }^{\circ} \mathrm{C}$ at $10{ }^{\circ} \mathrm{C},-0.007^{\circ} \mathrm{C}$ at $20^{\circ} \mathrm{C},-0.009^{\circ} \mathrm{C}$ at $30^{\circ} \mathrm{C}$ and zero at the melting point of ice and the boiling point of water.

In view of the above changes in the basis of reference for the volt and in the International Temperature Scale, changes in the voltage standard and in the results obtained by $W_{\text {olff }}$ on the emf-temperature coefficient become necessary. With these changes eq (29) and the alternate form, eq (31) become, respectively:

$E=E_{20}{ }^{\circ} \mathrm{C}-0.000004064(t-20)$

$-0.00000095006(t-20)^{2}+0.000000010034(t-20)^{3}$

and

$E=E_{0}{ }^{\circ} \mathrm{C}+0.0000094019 t$

$$
-0.0000015521 t^{2}+0.000000010034 t^{3}
$$

In table 3 the thermodynamic data for standard cells of the saturated cadmium sulfate type are given for temperatures from 0 to $43.6^{\circ} \mathrm{C}$ [ the transition temperature, $\left.\mathrm{CdSO}_{4} \cdot \frac{8}{3} \quad \mathrm{H}_{2} \mathrm{O}(\mathrm{s})=\mathrm{CdSO}_{4} \cdot \mathrm{H}_{2} \mathrm{O}(\mathrm{s})\right]$, inclusive, as calculated from emf data and eq (33) or eq (34). In this table the changes in emf from international to absolute (1948), to absolute (1969), and for the different temperature scales are given. The thermodynamic data given herein are calculated from the most recent values of the emf, i.e., on $\mathrm{V}_{69}$ and $t_{68}$. The emf at $20{ }^{\circ} \mathrm{C}$ in column 2 is that recommended by the International Committee on Electrical Units and Standards; it was based on the emf of cells prepared with mercurous sulfate made chemically or by dc electrolysis. Numerous investigations have indicated that mercurous sulfates prepared in different ways, providing they do not contain basic mercurous sulfate or mercuric ions, yield cells of the same emf. However, recent studies to be discussed in a subsequent paper, show that mercurous sulfate prepared by de electrolysis gives cells with an emf exceeding those in column 5 of table 3 by $16.8 \mu \mathrm{V}$. This difference is small and amounts to only $3.24 \mathrm{~J} \mathrm{~mol}^{-1}\left(0.77 \mathrm{cal} \mathrm{mol}^{-1}\right)$ in $\Delta G$ and $\Delta H$, see footnote to tables 3,4 , and 10 .

The uncertainties listed, $1 \sigma$, are mean standard deviations obtained from the data on the 99 cells measured by Wolff, and includes an uncertainty of $5.4 \mu \mathrm{V}^{\mathbf{9}}$ arising from the combined uncertainties in the absolute measurement of the ampere and the ohm.

\section{Comparisons of Calorimetric and Equilib- rium Data With Electrochemical (or Elec- trical) Data at $25^{\circ} \mathrm{C}$}

Comparisons of calorimetric and equilibrium data with electrochemical data are given in table 4 for $25^{\circ} \mathrm{C}$. Insufficient data are available for direct comparisons at other temperatures. Six facts are evident from inspection of the data, namely:

(1) Remarkable agreement is obtained for $\Delta G, \Delta H$, and $\Delta S$ between the calorimetric and equilibrium data (sum 2) and electrochemical data in Part I if the emf data for cell (A) obtained by Hulett [34] and Getman [35] are used for reaction (e). This agreement may be coincidental in view of the uncertainties in the older heat data or results from a cancellation of errors, but even so it adds weight to the reliability of the postulated chemical reactions for standard cells of the saturated cadmium sulfate type. For example, Harned and Owen [62] state "It should be emphasized ... that the nature of the chemical reactions, corresponding to a particular electrode, or cell, cannot be determined by electromotive force measurements alone. Cells reactions, no matter how simple and obvious, must be treated as hypothetical until it can be shown that thermodynamic quantities calculated from the electromotive force, $\Delta F[\Delta G], \Delta H$, equilibrium constants, etc. have been checked by other evidence."

(2) The difference of $1.722 \mathrm{~J} \mathrm{~K}^{-1} \mathrm{~mol}^{-1}(0.410 \mathrm{cal}$ $\mathrm{K}^{-1} \mathrm{~mol}^{-1}$ ) between the $\Delta C_{p}$ values (sum 2 and electrochemical) may well be accounted for by the data for cell (A) for which $\Delta C_{p}$ is zero. More careful measurements on cell (A) may well show that the emf of this cell as a function of temperature is second- or thirdorder rather than a linear function.

(3) The data show that the results of Parks and LaMer [39] for cell (A), although they give good agreement with calorimetric data for $\Delta G$, yield

\footnotetext{
9 This is a root sum square value. Recently, John Clarke [59] gave the uncertainty as $\pm 2.6 \mathrm{ppm}($ or $\mu \mathrm{V})$; this is about one half the root sum square uncertainty in published values for the absolute ampere [60] and the absolute ohm [61].
} 
TABLE 3. Electromotive forces and thermodynamic data for standard cells of the saturated cadmium sulfate type

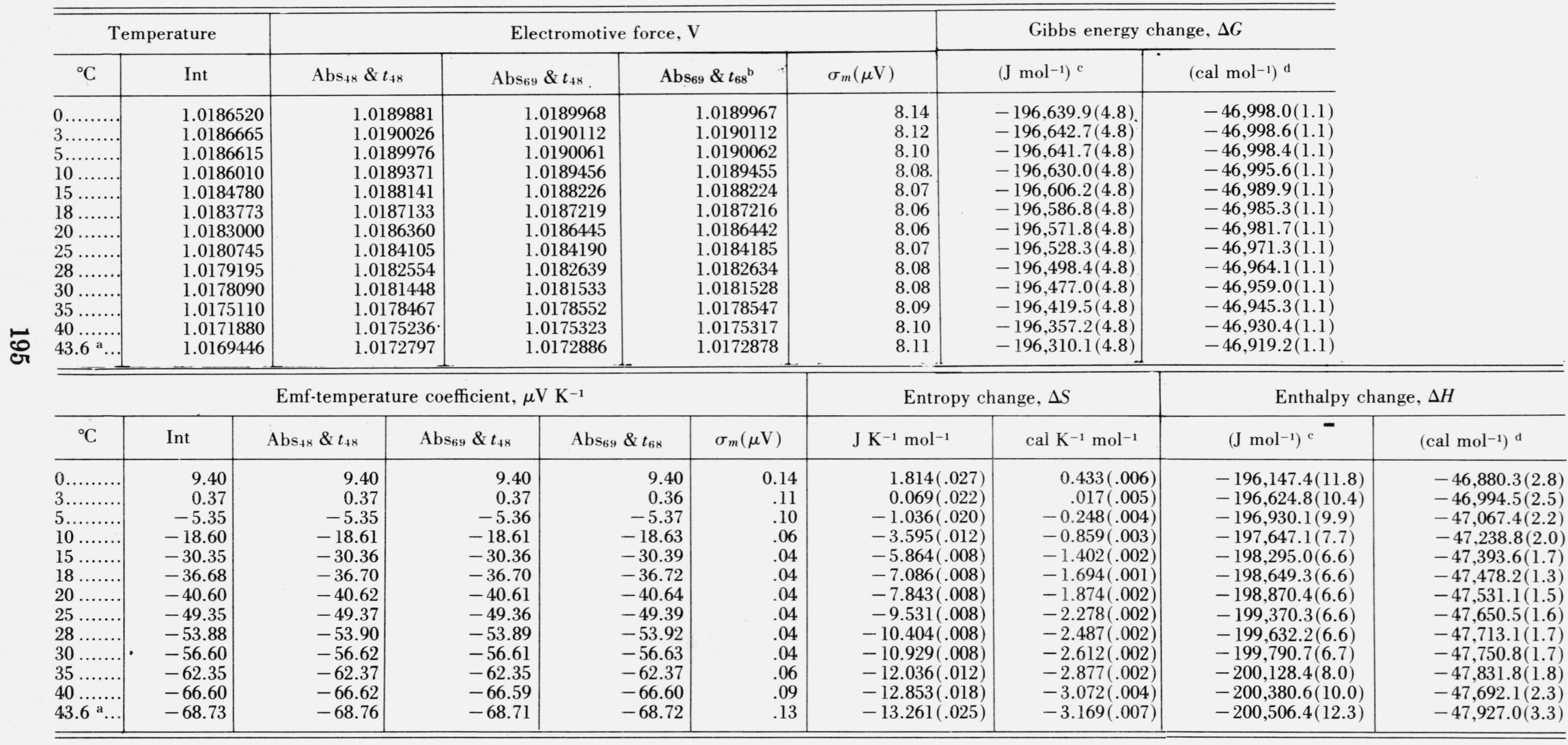


TABLE 3. Electromotive etc.-Continued

\begin{tabular}{|c|c|c|c|c|c|c|c|}
\hline${ }^{\circ} \mathrm{C}$ & Int & $\mathrm{Abs}_{48} \& t_{48}$ & $\operatorname{Abs}_{69} \& t_{48}$ & $\mathrm{Abs}_{69} \& t_{68}$ & $\sigma_{m}(\mu \mathrm{V})$ & $\mathrm{J} \mathrm{K}^{-1} \mathrm{~mol}^{-1}$ & cal K${ }^{-1} \mathrm{~mol}^{-1}$ \\
\hline
\end{tabular}

\footnotetext{
a All values at $43.6{ }^{\circ} \mathrm{C}$ are extrapolated values.

b Based on combined results obtained with chemically-prepared and dc-electrolytic mercurous sulfate; the values are $18.6 \mu \mathrm{V}$ higher for dc-electrolytic mercurous sulfate alone.

${ }^{\mathrm{c}}$ Higher by $3.24 \mathrm{~J} \mathrm{~mol}^{-1}$ for dc-electrolytic mercurous sulfate alone.

${ }^{d}$ Higher by $0.77 \mathrm{cal} \mathrm{mol}^{-1}$ for de-electrolytic mercurous sulfate alone.
}

results for $\Delta H, \Delta S$, and especially $\Delta C_{p}$ (actually of opposite sign) that differ widely from the electrochemical data on standard cells of the saturated cadmium sulfate type. Actually, Parks and LaMer gave too much weight to an apparent curvature in the variation of the emf of cell (A) with temperature.

(4) The enthalpy data of Papadopoulos and Giauque [21] lead to values for $\Delta G$ and $\Delta H$ that are lower than the electrochemical values by $301.3 \mathrm{~J} \mathrm{~mol}^{-1}$ (71.9 cal mol-1) and $290.0 \mathrm{~J} \mathrm{~mol}^{-1}\left(69.3 \mathrm{cal} \mathrm{mol}^{-1}\right)$, respectively. These differences which amount, respectively, to only 0.16 percent and 0.15 percent, are beyond the uncertainties estimated by Papadopoulos and Giauque. Sometimes cadmium sulfate contains occluded sulfuric acid (especially if digested in sulfuric acid during the purification) which would cause a decrease in $\Delta G$ and $\Delta H$ for the cell reaction (see conclusions to this paper). Such occlusions could not explain the above differences in $\Delta G$ and $\Delta H$ between the calorimetric and electromotive force data since the occlusions would have to amount to about 1 molai $\mathrm{H}_{2} \mathrm{SO}_{4}$ (see conclusions to this paper) which is entirely out of the range of possibility.

(5) If the alternate heat capacity data for reaction (a), discussed above, are used they yield a value for sum 2 which differs more from the electrochemical value than the value given in table 4 (actually, the alternate heat capacity data for reaction (a) yield -94.231 J K ${ }^{-1} \mathrm{~mol}^{-1}\left(-22.474 \mathrm{cal} \mathrm{K}^{-1} \mathrm{~mol}^{-1}\right)$ for sum 2 rather than the value shown).

(6) The enthalpy data of Papadoupolos and Giauque [21], if used with the enthalpy data of Bichowsky and Rossini [12], corrected to $25^{\circ} \mathrm{C}$, or the enthalpy data of Circular 500 [23] or the enthalpy data of revised NBS Circular $[24,30]$ still do not agree with the electrochemical data.

TABLE 4. Comparison of calorimetric and equilibrium data with electromotive force data

Part I-Based on table 1: experimental values of $\Delta G$ for reactions (b), (c), and (d) and of $\Delta H$ for reactions (a) and (b)

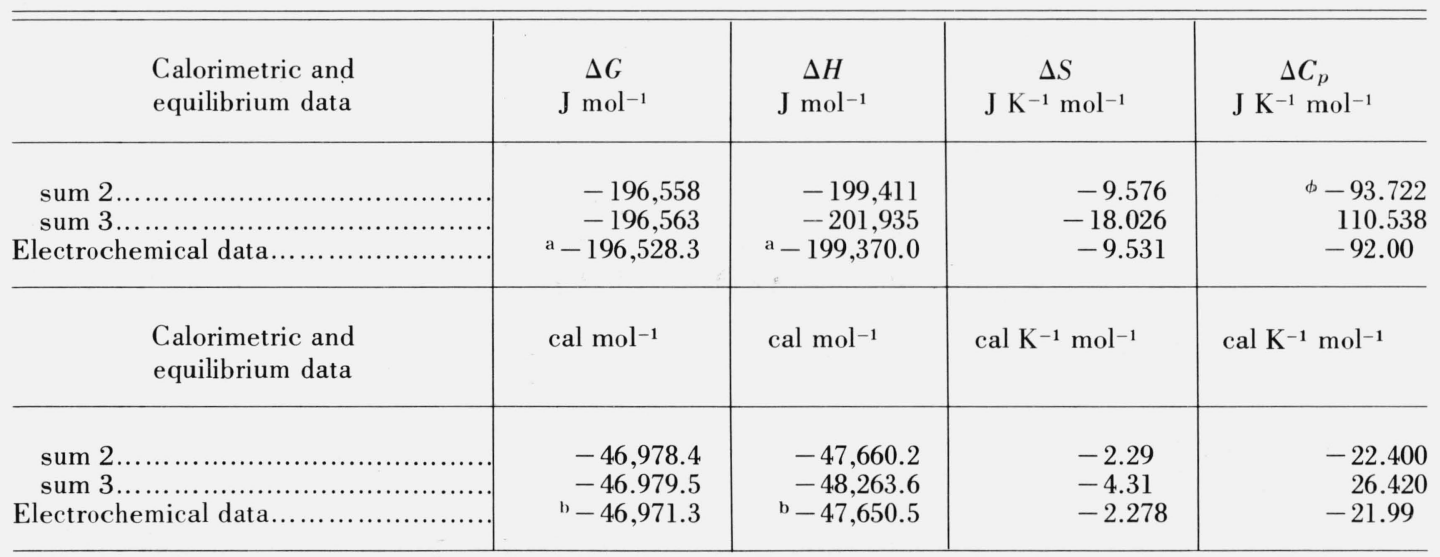


TABLE 4. Comparison etc.-Continued

Part II - Based on table 2: experimental values of $\Delta G$ for reaction (d) and of $\Delta H$ for reactions (a), (b), (c), and (d)

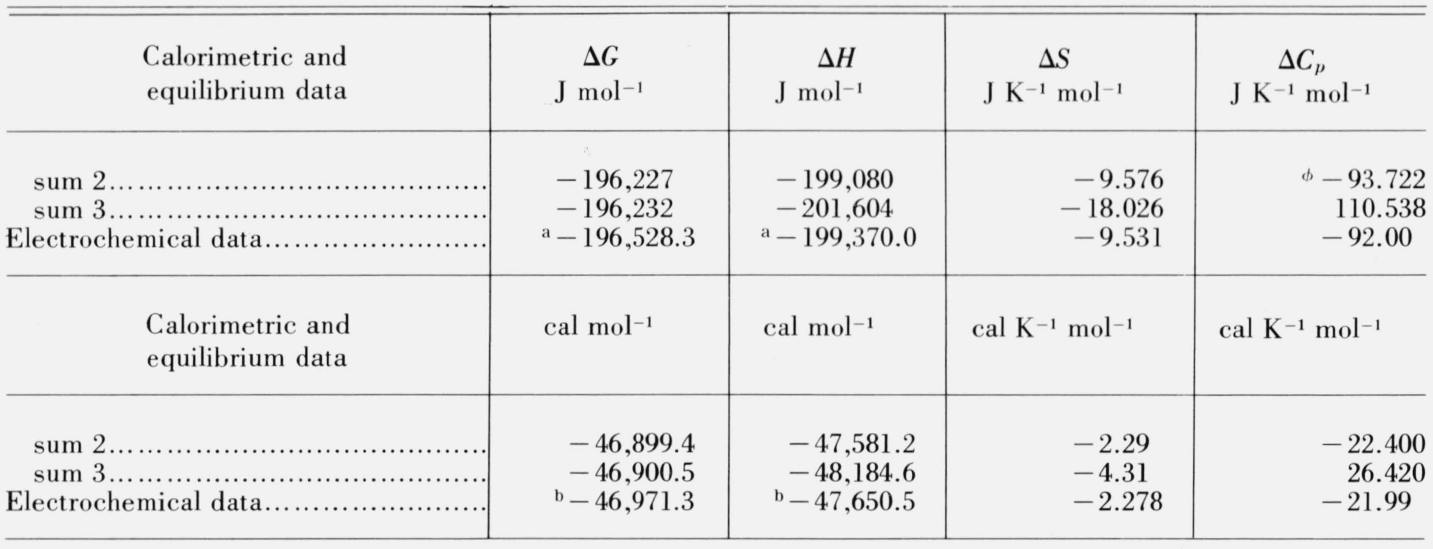

$\phi$ See tables 1 and 2 for a note on an alternate value.

a Higher by $3.24 \mathrm{~J} \mathrm{~mol}^{-1}$ for de-electrolytic mercurous sulfate.

b Higher by $0.77 \mathrm{cal} \mathrm{mol}^{-1}$ for de-electrolytic mercurous sulfate.

\section{Range of Precision in Emf Results}

In table 3 it is evident that the uncertainties in the data are greater at the two ends of the temperature range. For the emf, these reside in the experimental measurements but for the derived quantities, $\Delta H, \Delta S$, and $\Delta C_{p}$, they may be dependent in addition on the emf-temperature function used to represent the data. Since the emf data available on the standard cell of the saturated cadmium sulfate type are known with high precision they may be used to illustrate the effect an emf-temperature function has on the derived thermodynamic data. Accordingly, the emf data of table 3 were fitted (method of least squares) to second-, third-, and fourth-order equations in the temperature of the form (fourth order shown):

$$
E=E_{0}{ }^{\circ} \mathrm{C}+\alpha t+\beta t^{2}+\gamma t^{3}+\delta t^{4} .
$$

Also, since the literature $[11,62-65]$ is filled with results on the measurements of the emfs of galvanic cells to only $0.01 \mathrm{mV}$ or $10 \mu \mathrm{V}$, and over a range of temperatures, the emf data of table 3 were rounded to $0.01 \mathrm{mV}$ and then fitted (method of least squares) to second-, third-, and fourth-order equations in the temperature of the form of eq (35). The coefficients of the form equations for the several procedures are given in table 5 .

Results are given in tables $6,7,8$, and 9. In table 6 the emfs are given as obtained for fourth-, third-, and second-order equations and for emfs either known to $0.01 \mu \mathrm{V}$ or rounded to $0.01 \mathrm{mV}$. Inspection shows that either third- or fourth-order equations may be used to represent the emfs. ${ }^{10}$ Inspection also shows that the differences in $\Delta G$ are practically negligible between the fourth- and third-order fits. If the preci-

\footnotetext{
${ }^{10}$ Since the values in table 3 were generated from a third-order equation [see eqs (33) or (34) ], the fit of a fourth-order equation would be no better than that of a third-order. How ever, derived quantities, especially $\Delta C_{p}$, may be slightly different; actually the difference gives an estimate of the uncertainty in the derived quantity.
}

sion of the observations is lowered to $0.01 \mathrm{mV}$ (table 7) the errors in $\Delta G$ are still practically negligible between the fourth- and third-order fits (see footnote 10). As expected, however, second-order equations are inadequate to represent $E$ and $\Delta G$ with either resolutions of $0.1 \mu \mathrm{V}$ or $0.01 \mathrm{mV}$ in $E$.

For $\Delta S$ and $\Delta C_{p}$ the situation is quite different, see tables 8 and 9 . Values of $\Delta S$ as given by fourth and third order equations are practically the same, except above $40{ }^{\circ} \mathrm{C}$ or at $0{ }^{\circ} \mathrm{C}$ for a resolution of $0.1 \mu \mathrm{V}$ in $E$ but differ from 0.013 to $0.179 \mathrm{~J} \mathrm{~K}^{-1} \mathrm{~mol}^{-1}(0.007$ to $0.043 \mathrm{cal} \mathrm{K}^{-1} \mathrm{~mol}^{-1}$ ) for a resolution of $0.01 \mathrm{mV}$ in $E$. Particular attention should be given to a comparison, say at $25{ }^{\circ} \mathrm{C}$, between a fourth (or third) order fit to $0.1 \mu \mathrm{V}$ in $E$ and a second order fit to $0.01 \mathrm{mV}$ in $E$ (most common procedure reported in the literature); a difference of $0.607(0.606) \mathrm{J} \mathrm{K}^{-1} \mathrm{~mol}^{-1}(0.145 \mathrm{cal}$ $\mathrm{K}^{-1} \mathrm{~mol}^{-1}$ ) is obtained. This difference is large and has mistakenly lead some observers [66-69], under similar cases, to conclude that the emf measurements

TABLE 5. Coefficients in the equation: $\mathrm{E}=\mathrm{E}_{0^{\circ}}+\alpha \mathrm{t}+\beta \mathrm{t}^{2}+\gamma \mathrm{t}^{3}+\delta \mathrm{t}^{4}$

(On $\mathrm{V}_{69}$ and $t_{68}$ scales)

(to $0.1 \mu \mathrm{V}$ )

\begin{tabular}{|c|c|c|c|c|c|}
\hline Order & $E_{0^{\circ}}$ & $\alpha \times 10^{6}$ & $\beta \times 10^{6}$ & $\gamma \times 10^{9}$ & $\delta \times 10^{11}$ \\
\hline 4th & 1.0189968 & 9.3415 & -1.5454 & 9.7894 & 0.27990 \\
\hline $3 \mathrm{~d}$ & 1.0189967 & 9.4019 & -1.5521 & 10.034 & \\
\hline $2 \mathrm{~d}$ & 1.0190260 & -1.5507 & -0.89411 & & \\
\hline
\end{tabular}

(to $0.01 \mathrm{mV}$ or $10 \mu \mathrm{V}$ )

\begin{tabular}{|c|c|c|c|c|c|}
\hline 4 th & 1.01900 & 9.9747 & -1.6498 & 13.828 & -4.2920 \\
\hline d & 1.01900 & 9.0481 & -1.5469 & 10.082 & \\
\hline d & 1.01903 & -1.9569 & -0.88584 & & \\
\hline
\end{tabular}


TABLE 6. Results from fourth, third, and second order equations for the emf of standard cells of the saturated cadmium sulfate type as a function of temperature (to $0.1 \mu \mathrm{V}$ )

\begin{tabular}{|c|c|c|c|c|c|c|c|c|c|}
\hline \multirow{3}{*}{ Temperature, ${ }^{\circ} \mathrm{C}$} & \multirow{2}{*}{\multicolumn{3}{|c|}{ Electromotive force, $\mathrm{V}$}} & \multicolumn{4}{|c|}{$\Delta$ in $\Delta G}$, & \multirow{2}{*}{\multicolumn{2}{|c|}{$\begin{array}{l}\Delta \text { in } \Delta G, \\
\mathrm{cal} \mathrm{mol}^{-1}\end{array}$}} \\
\hline & & & & \multicolumn{2}{|c|}{$\Delta E, \mu \mathrm{V}$} & \multicolumn{2}{|c|}{$\mathrm{J} \mathrm{mol} \mathrm{m}^{-1}$} & & \\
\hline & 4 th order & $3 \mathrm{~d}$ order & $2 \mathrm{~d}$ order & $4-3$ & $4-2$ & $4-3$ & $4-2$ & $4-3$ & $4-3$ \\
\hline $0 .$. & 1.0189968 & 1.0189967 & 1.0190260 & 0.1 & -29.2 & 0.02 & -5.63 & 0.005 & -1.35 \\
\hline $3 .$. & 1.0190112 & 1.0190112 & 1.0190133 & 0 & -2.1 & 0 & -0.41 & 0 & -0.10 \\
\hline $5 \ldots$ & 1.0190061 & 1.0190062 & 1.0189959 & -0.1 & 10.2 & -0.02 & 1.97 & -0.005 & 0.47 \\
\hline $10 .$. & 1.0189455 & 1.0189455 & 1.0189211 & 0 & 24.4 & 0 & 4.71 & 0 & 1.13 \\
\hline $15 \ldots$ & 1.0188224 & 1.0188224 & 1.0188012 & 0 & 21.2 & 0 & 4.09 & 0 & 0.98 \\
\hline $18 \ldots$ & 1.0187217 & 1.0187216 & 1.0187084 & 0.1 & 13.3 & 0.02 & 2.57 & 0.005 & 0.61 \\
\hline $20 \ldots$ & 1.0186443 & 1.0186442 & 1.0186373 & 0.1 & 7.0 & .02 & 1.35 & .005 & .32 \\
\hline $25 \ldots$ & 1.0184186 & 1.0184185 & 1.0184284 & 0.1 & -9.8 & .02 & -1.89 & .005 & -0.45 \\
\hline $28 \ldots$ & 1.0182635 & 1.0182634 & 1.0182816 & 0.1 & -18.1 & .02 & -3.49 & .005 & -0.83 \\
\hline $30 \ldots$ & 1.0181529 & 1.0181528 & 1.0181748 & 0.1 & -21.9 & .02 & -4.23 & .005 & -1.01 \\
\hline $35 \ldots$ & 1.0178547 & 1.0178547 & 1.0178764 & 0 & -21.7 & .02 & -4.19 & .005 & -1.00 \\
\hline $40 \ldots$ & 1.0175317 & 1.0175316 & 1.0175334 & 0.1 & -1.7 & .02 & -0.33 & .005 & -0.08 \\
\hline $43.6^{\mathrm{a}} .$. & 1.0172880 & 1.0172878 & 1.0172587 & 0.2 & 29.3 & .04 & 5.65 & .01 & 1.35 \\
\hline
\end{tabular}

${ }^{\text {a }}$ Extrapolated values.

TABLE 7. Results from fourth, third, and second order equations for the emf of standard cells of the saturated cadmium sulfate type as a function of temperature (to $0.01 \mathrm{mV}$ or $10 \mu \mathrm{V}$ )

\begin{tabular}{|c|c|c|c|c|c|c|c|c|c|}
\hline \multirow{3}{*}{ Temperature, ${ }^{\circ} \mathrm{C}$} & \multirow{2}{*}{\multicolumn{3}{|c|}{ Electromotive force, $\mathrm{V}$}} & \multicolumn{4}{|c|}{$\Delta$ in $\Delta G$} & \multirow{2}{*}{\multicolumn{2}{|c|}{$\begin{array}{l}\Delta \text { in } \Delta G, \\
\mathrm{cal} \mathrm{mol}^{-1}\end{array}$}} \\
\hline & & & & \multicolumn{2}{|c|}{$\Delta E, \mathrm{mV}$} & \multicolumn{2}{|c|}{$\mathrm{J} \mathrm{mol}^{-1}$} & & \\
\hline & 4th order & $3 \mathrm{~d}$ order & $2 \mathrm{~d}$ order & $4-3$ & $4-2$ & 4.3 & $4-2$ & $4-3$ & $4-2$ \\
\hline $0 \ldots$ & 1.01900 & 1.01900 & 1.01903 & 0 & -0.03 & 0 & -5.79 & 0 & -1.38 \\
\hline $3 \ldots \ldots$ & 1.01902 & 1.01901 & 1.01902 & 0.01 & 0 & 1.93 & 0 & 0.46 & 0 \\
\hline $5 \ldots$ & 1.01901 & 1.01901 & 1.01900 & 0 & 0.01 & 0 & 1.93 & 0 & 0.46 \\
\hline $10 \ldots \ldots$ & 1.01895 & 1.01895 & 1.01892 & 0 & .03 & 0 & 5.79 & 0 & 1.38 \\
\hline $15 \ldots \ldots$ & 1.01882 & 1.01882 & 1.01880 & 0 & .02 & 0 & 3.86 & 0 & 0.92 \\
\hline $18 \ldots$ & 1.01872 & 1.01872 & 1.01871 & 0 & .01 & 0 & 1.93 & 0 & .46 \\
\hline $20 \ldots$ & 1.01864 & 1.01864 & 1.01864 & 0 & 0 & 0 & 0 & 0 & 0 \\
\hline $25 \ldots$ & 1.01842 & 1.01842 & 1.01843 & 0 & -0.01 & 0 & -1.93 & 0 & -0.46 \\
\hline $28 \ldots$ & 1.01826 & 1.01826 & 1.01828 & 0 & -0.02 & 0 & -3.86 & 0 & -0.92 \\
\hline $30 \ldots$ & 1.01815 & 1.01815 & 1.01817 & 0 & -0.02 & 0 & -3.86 & 0 & -0.92 \\
\hline $35 \ldots$ & 1.01786 & 1.01785 & 1.01788 & 0.01 & -0.02 & 1.93 & -3.86 & 0.46 & -0.92 \\
\hline $40 \ldots$ & 1.01753 & 1.01753 & 1.01753 & 0 & 0 & 0 & 0 & 0 & 0 \\
\hline $43.6^{\mathrm{a}}$. & 1.01729 & 1.01729 & 1.01726 & 0 & 0.03 & 0 & 5.79 & 0 & 1.38 \\
\hline
\end{tabular}

axtrapolated values.

are in error whereas, in fact, the differences arise from a lack of resolution or in imprecision of the instruments employed. For $\Delta C_{p}$, this situation is even more marked, see table 9. Values of $\Delta C_{p}$, as given by fourth and third order equations are nearly the same, although the fourth-order results are probably preferable, if the resolution in $E$ is $0.1 \mu \mathrm{V}$. However, for a resolution of only $0.01 \mathrm{mV}$ in $E$, large differences are found between fourth and third order fits, but the third-order fits agree more closely with the fourth and third order fits on $0.1 \mu \mathrm{V}$ resolution in $E$; third-order fits are, therefore, selected as final representations, in line with eqs (29) and (31) given above. As above for $\Delta S$, particular attention should be given to a comparison, say at $25{ }^{\circ} \mathrm{C}$, between a third-order fit to $0.1 \mu \mathrm{V}$ in $E$ and a second order fit to $0.01 \mathrm{mV}$ in $E$ (most common procedure reported in the literature); a difference of 9.93 $\mathrm{J} \mathrm{K}^{-1} \mathrm{~mol}^{-1}\left(2.37 \mathrm{cal} \mathrm{K}^{-1} \mathrm{~mol}^{-1}\right)$ is obtained. This value is again large and has mistakenly lead some observers [66-69], under similar cases, to conclude that the emf measurements are in error by as much as $1 \mathrm{mV}$ whereas, in fact, the differences rest with the degree of resolution in the measuring equipment.

The situation in regard to both $\Delta S$ and $\Delta C_{p}$ is more serious at the extremes of temperature. This is shown in figures 1 and 2 . It is obvious from these figures that $\Delta S$ and $\Delta C_{p}$, as determined from emfs of different resolutions and equations of different order differ at the extremes of temperature and that in order to determine them, especially $\Delta C_{p}$, at $0{ }^{\circ} \mathrm{C}$ and $40{ }^{\circ} \mathrm{C}$ 
TABLE 8. Entropy changes for reactions in standard cells of the saturated cadmium sulfate type as calculated by different functions

\begin{tabular}{|c|c|c|c|c|c|c|c|c|c|c|c|c|}
\hline \multicolumn{4}{|c|}{ (to $0.1 \mu \mathrm{V}$ in $E$ ) } & \multicolumn{3}{|c|}{ (to $0.01 \mathrm{mV}$ or $10 \mu \mathrm{V}$ in $E$ ) } & \multicolumn{3}{|c|}{ (to $0.1 \mu \mathrm{V}$ in $E$ ) } & \multicolumn{3}{|c|}{ (to $0.01 \mathrm{mV}$ or $10 \mu \mathrm{V}$ in $E$ ) } \\
\hline \multicolumn{7}{|c|}{$\mathrm{J} \mathrm{K}^{-1} \mathrm{~mol}^{-1}$} & \multicolumn{6}{|c|}{ cal $\mathrm{K}^{-1} \mathrm{~mol}^{-1}$} \\
\hline $\begin{array}{c}\text { Temperature, } \\
{ }^{\circ} \mathrm{C}\end{array}$ & 4 th order & $3 \mathrm{~d}$ order & $2 \mathrm{~d}$ order & 4 th order & $3 \mathrm{~d}$ order & $2 \mathrm{~d}$ order & 4 th order & $3 \mathrm{~d}$ order & $2 \mathrm{~d}$ order & 4 th order & $3 \mathrm{~d}$ order & $2 \mathrm{~d}$ order \\
\hline 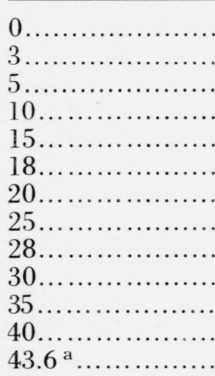 & $\begin{array}{r}1.803 \\
0.065 \\
-1.037 \\
-3.592 \\
-5.861 \\
-7.084 \\
-7.841 \\
-9.532 \\
-10.406 \\
-10.931 \\
-12.036 \\
-12.849 \\
-13.248\end{array}$ & $\begin{array}{r}1.814 \\
0.069 \\
-1.036 \\
-3.595 \\
-5.864 \\
-7.086 \\
-7.843 \\
-9.531 \\
-10.404 \\
-10.929 \\
-12.036 \\
-12.853 \\
-13.261\end{array}$ & $\begin{array}{l}-0.299 \\
-1.334 \\
-2.025 \\
-3.750 \\
-5.475 \\
-6.511 \\
-7.201 \\
-8.926 \\
-9.961 \\
-10.652 \\
-12.377 \\
-14.102 \\
-15.345\end{array}$ & $\begin{array}{r}1.925 \\
0.086 \\
-1.063 \\
-3.675 \\
-5.937 \\
-7.136 \\
-7.873 \\
-9.508 \\
-10.355 \\
-10.867 \\
-11.975 \\
-12.856 \\
-13.365\end{array}$ & $\begin{array}{r}1.746 \\
0.008 \\
-1.093 \\
-3.640 \\
-5.896 \\
-7.109 \\
-7.860 \\
-9.532 \\
-10.395 \\
-10.912 \\
-12.000 \\
-12.796 \\
-13.189\end{array}$ & $\begin{array}{l}-0.378 \\
-1.403 \\
-2.087 \\
-3.797 \\
-5.506 \\
-6.532 \\
-7.215 \\
-8.925 \\
-9.950 \\
-10.634 \\
-12.344 \\
-14.053 \\
-15.284\end{array}$ & $\begin{array}{r}0.431 \\
0.015 \\
-0.248 \\
-0.859 \\
-1.401 \\
-1.693 \\
-1.874 \\
-2.278 \\
-2.487 \\
-2.612 \\
-2.877 \\
-3.071 \\
-3.166\end{array}$ & $\begin{array}{r}0.433 \\
0.017 \\
-0.248 \\
-0.859 \\
-1.402 \\
-1.694 \\
-1.874 \\
-2.278 \\
-2.487 \\
-2.612 \\
-2.877 \\
-3.072 \\
-3.169\end{array}$ & $\begin{array}{l}-0.072 \\
-0.319 \\
-0.484 \\
-0.896 \\
-1.309 \\
-1.556 \\
-1.721 \\
-2.133 \\
-2.381 \\
-2.546 \\
-2.958 \\
-3.371 \\
-3.667\end{array}$ & $\begin{array}{r}0.460 \\
0.021 \\
-0.254 \\
-0.878 \\
-1.419 \\
-1.706 \\
-1.882 \\
-2.272 \\
-2.475 \\
-2.597 \\
-2.862 \\
-3.073 \\
-3.194\end{array}$ & $\begin{array}{r}0.417 \\
.002 \\
-0.261 \\
-0.870 \\
-1.409 \\
-1.699 \\
-1.879 \\
-2.278 \\
-2.484 \\
-2.608 \\
-2.868 \\
-3.058 \\
-3.152\end{array}$ & $\begin{array}{l}-0.090 \\
-0.335 \\
-0.499 \\
-0.907 \\
-1.316 \\
-1.561 \\
-1.725 \\
-2.133 \\
-2.378 \\
-2.542 \\
-2.950 \\
-3.359 \\
-3.653\end{array}$ \\
\hline
\end{tabular}

${ }^{\text {a }}$ Extrapolated values.

TABLE 9. Heat capacity changes for the reaction in standard cells of the saturated cadmium sulfate type as calculated by different functions

\begin{tabular}{|c|c|c|c|c|c|c|c|c|c|c|c|c|}
\hline \multicolumn{4}{|c|}{ (to $0.1 \mu \mathrm{V}$ in $E$ ) } & \multicolumn{3}{|c|}{ (to $0.01 \mathrm{mV}$ or $10 \mu \mathrm{V}$ in $E$ ) } & \multicolumn{3}{|c|}{ (to $0.1 \mu \mathrm{V}$ in $E$ ) } & \multicolumn{3}{|c|}{ (to $0.01 \mathrm{mV}$ or $10 \mu \mathrm{V}$ in $E$ ) } \\
\hline \multicolumn{7}{|c|}{$\mathrm{J} \mathrm{K}^{-1} \mathrm{~mol}^{-1}$} & \multicolumn{6}{|c|}{ cal K $\mathrm{K}^{-1} \mathrm{~mol}^{-1}$} \\
\hline $\begin{array}{l}\text { Temperature, } \\
{ }^{\circ} \mathrm{C}\end{array}$ & 4 th order & $3 \mathrm{~d}$ order & $2 \mathrm{~d}$ order & 4 th order & $3 \mathrm{~d}$ order & $2 \mathrm{~d}$ order & 4 th order & $3 \mathrm{~d}$ order & $2 \mathrm{~d}$ order & 4 th order & $3 \mathrm{~d}$ order & $2 \mathrm{~d}$ order \\
\hline 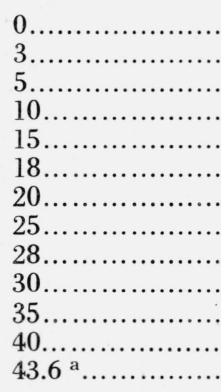 & $\begin{array}{l}-162.91 \\
-155.29 \\
-150.08 \\
-136.59 \\
-122.44 \\
-113.63 \\
-107.62 \\
-92.12 \\
-82.50 \\
-75.95 \\
-59.09 \\
-41.54 \\
-28.47\end{array}$ & $\begin{array}{l}-163.62 \\
-155.80 \\
-150.46 \\
-136.72 \\
-122.40 \\
-113.52 \\
-107.49 \\
-92.00 \\
-82.43 \\
-75.94 \\
-59.29 \\
-42.06 \\
-29.30\end{array}$ & $\begin{array}{l}-94.26 \\
-95.29 \\
-95.98 \\
-97.71 \\
-99.43 \\
-100.47 \\
-101.16 \\
-102.89 \\
-103.92 \\
-104.61 \\
-106.34 \\
-108.06 \\
-109.30\end{array}$ & $\begin{array}{l}-173.92 \\
-162.82 \\
-155.53 \\
-137.77 \\
-120.72 \\
-110.85 \\
-104.44 \\
-89.02 \\
-80.21 \\
-74.53 \\
-61.05 \\
-48.64 \\
-40.42\end{array}$ & $\begin{array}{l}-162.96 \\
-155.08 \\
-149.71 \\
-135.87 \\
-121.45 \\
-112.52 \\
-106.45 \\
-90.87 \\
-81.23 \\
-74.69 \\
-57.94 \\
-40.60 \\
-27.76\end{array}$ & $\begin{array}{l}-93.39 \\
-94.41 \\
-95.10 \\
-96.81 \\
-98.51 \\
-99.54 \\
-100.22 \\
-101.93 \\
-102.96 \\
-103.64 \\
-105.35 \\
-107.06 \\
-108.29\end{array}$ & $\begin{array}{l}-38.94 \\
-37.12 \\
-35.87 \\
-32.65 \\
-29.26 \\
-27.16 \\
-25.72 \\
-22.02 \\
-19.72 \\
-18.15 \\
-14.12 \\
-9.93 \\
-6.81\end{array}$ & $\begin{array}{l}-39.11 \\
-37.24 \\
-35.96 \\
-32.68 \\
-29.25 \\
-27.13 \\
-25.69 \\
-21.99 \\
-19.70 \\
-18.14 \\
-14.17 \\
-10.05 \\
-7.00\end{array}$ & $\begin{array}{l}-22.53 \\
-22.78 \\
-22.94 \\
-23.35 \\
-23.77 \\
-24.01 \\
-24.18 \\
-24.59 \\
-24.84 \\
-25.00 \\
-25.41 \\
-25.83 \\
-26.12\end{array}$ & $\begin{array}{l}-41.57 \\
-38.91 \\
-37.17 \\
-32.93 \\
-28.85 \\
-26.50 \\
-24.96 \\
-21.28 \\
-19.17 \\
-17.81 \\
-14.59 \\
-11.63 \\
-9.66\end{array}$ & $\begin{array}{l}-38.95 \\
-37.07 \\
-35.78 \\
-32.48 \\
-29.03 \\
-26.89 \\
-25.44 \\
-21.72 \\
-19.42 \\
-17.85 \\
-13.85 \\
-9.71 \\
-6.64\end{array}$ & $\begin{array}{l}-22.32 \\
-22.57 \\
-22.73 \\
-23.14 \\
-23.55 \\
-23.79 \\
-23.95 \\
-24.36 \\
-24.61 \\
-24.77 \\
-25.18 \\
-25.59 \\
-25.88\end{array}$ \\
\hline
\end{tabular}

a Extrapolated values. 


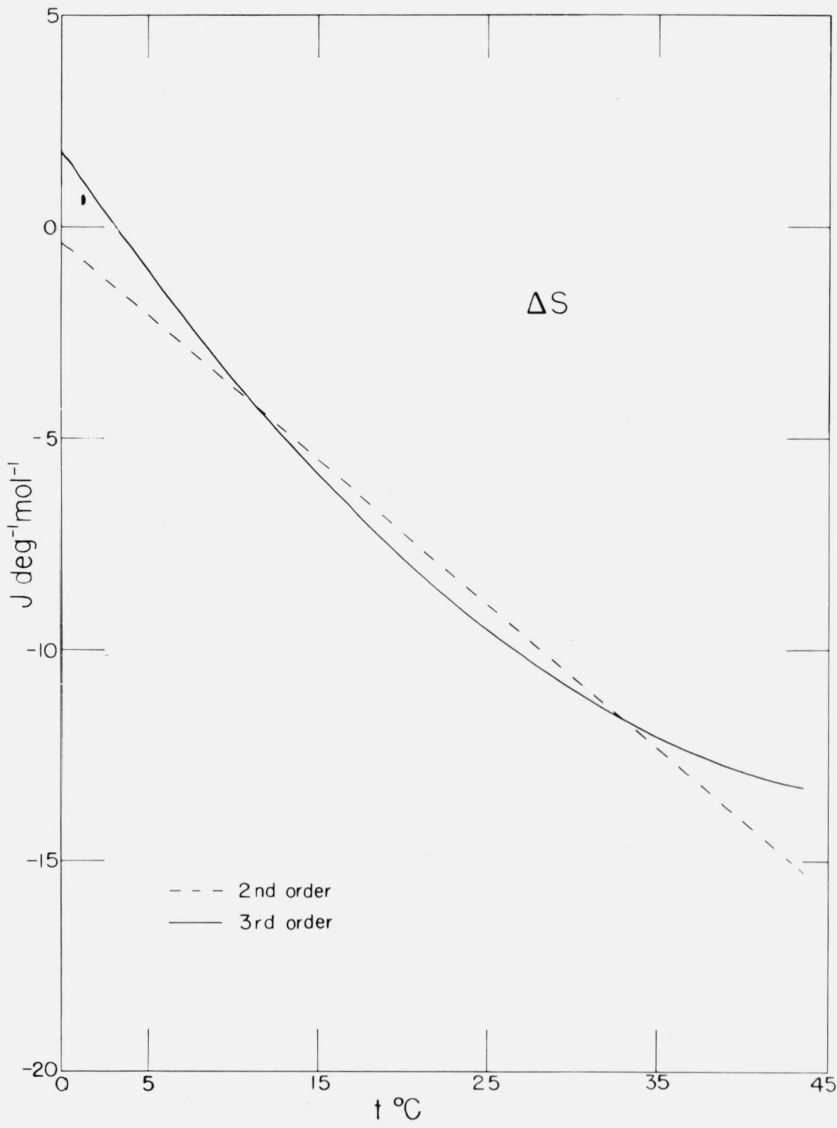

FIGURE 1. Temperature variations in entropy change for the reaction in standard cells of the saturated cadmium sulfate type, as determined by different functions.

(Fourth-order function gives nearly the same results as the third-order function and is therefore, not shown)

with the certainty shown at $25{ }^{\circ} \mathrm{C}$, higher resolution in emf and studies over a broader temperature range, ${ }^{11}$ if possible, are necessary.

\section{Alternate Emf Studies}

In the foregoing sections calorimetric and equilibrium data relating to standard cells of the saturated cadmium sulfate type were compared with emf data of such cells. In this section emf data on various cells, which in combination, yield a saturated cadmium sulfate cell, will be compared with the emf of the saturated cadmium sulfate cell. Comparisons are limited to $25^{\circ} \mathrm{C}$ where sufficient data are on hand.

Harned and Hamer [70] obtained $0.96495 \mathrm{~V}$ (converted to the $\mathrm{V}_{69}$ scale) at $25{ }^{\circ} \mathrm{C}$ for the emf of the cell:

\footnotetext{
${ }^{11}$ It would appear, at first glance, that Vigoureux and Watts [54] met this criterion, since they carried their measurements to $-20^{\circ} \mathrm{C}$ thus making possible a good evaluation of $\Delta C_{p}$ at $0{ }^{\circ} \mathrm{C}$. However, the emf goes through a maximum at $3{ }^{\circ} \mathrm{C}$, thus limiting the effec tiveness of a second-order equation to a narrow range of $3{ }^{\circ} \mathrm{C}$ to $-20^{\circ} \mathrm{C}$, thereby not providing sufficient resolution for $\Delta C_{p}$ at $0^{\circ} \mathrm{C}$. In cases where a maximum or minimum viding emf did not occur extension of measurements to $-20^{\circ} \mathrm{C}$ or lower would enhance the evaluation of $\Delta C_{p}$ by a second-order equation. However, higher order equations should be used.
}

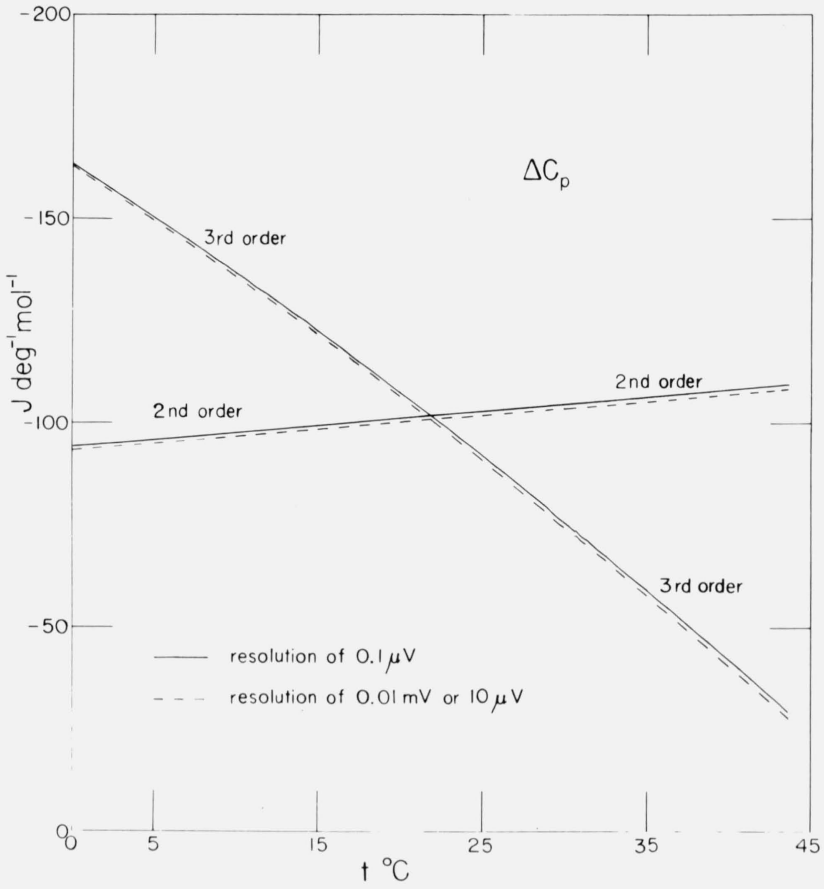

Figure 2. Temperature variations in heat-capacity change for the reaction in standard cells of the saturated cadmium sulfate type, as determined by different functions.

(Fourth-order function gives slightly different values than the third-order function, see text, table 9 , for values).

(-) $\mathrm{Pb}-\mathrm{Hg}(2 p)\left|\mathrm{PbSO}_{4}(\mathrm{~s})\right| \mathrm{Na}_{2} \mathrm{SO}_{4}(\mathrm{sol}) \mid$

$$
\mathrm{Hg}_{2} \mathrm{SO}_{4}(\mathrm{~s}) \mid \mathrm{Hg}(\mathrm{l})(+)
$$

LaMer and Parks [71] obtained $0.0013 \mathrm{~V}$ for the standard emf, $E^{0}$, of the cell:

$$
\begin{array}{r}
(+) \mathrm{Pb}-\mathrm{Hg}(2 p)\left|\mathrm{PbSO}_{4}(\mathrm{~s})\right| \mathrm{CdSO}_{4}(a=1) \mid \\
\mathrm{Cd}-\mathrm{Hg}(11 \%)(-)
\end{array}
$$

using the Gronwall, LaMer, and Sandved [72] treatment of interionic attraction to obtain $E^{0}$. Here $a$ denotes activity of the solute. On converting to absolute volts and using recent values of the physical constants [1] and the dielectric constant of water [73], it was found that the Gronwall, LaMer, and Sandved treatment did not lead to constant values of $E^{0}$ for the emf data of LaMer and Parks at the various concentrations of $\mathrm{CdSO}_{4}$. However, a straight-line extrapolation to $m=0$ to obtain $E^{0}$ follows by taking $\mathrm{CdSO}_{4}$ as incompletely dissociated with a dissociation constant of $0.0059 \mathrm{~mol} \mathrm{~kg} \mathrm{~kg}^{-1}$ at $25^{\circ} \mathrm{C}$ (an ion size of $3 \AA$ was used in the extrapolation). Extrapolations to $m=0$ gives $0.00184 \mathrm{~V}$ instead of $0.0013 \mathrm{~V}$, given by LaMer and Parks. ${ }^{12}$

${ }^{12}$ In their 1931 paper LaMer and Parks gave results at 0 and $25^{\circ} \mathrm{C}$. In their 1933 pape (stated to give better results) they gave results of measurments at $0,10,20$, and $30{ }^{\circ} \mathrm{C}$, but not for $25{ }^{\circ} \mathrm{C}$. Using the above treatment, i.e., taking $\mathrm{CdSO}_{4}$ as incompletely dissociated, $E^{0}$ was calculated at these four temperat ures which were then fitted to a third-order equation using least squares to give: $E^{0}$ (in volts) $=0.01698-0.0003588 t-0.000012949 t^{2}+$ $0.00000012328 t^{3}$ At $25{ }^{\circ} \mathrm{C}$ this equation yields $0.00184 \mathrm{~V}$, the value given above for $E^{\circ}$ also interpolation of the data for the dissociation constants for these temperatures gives $0.0059 \mathrm{~mol} \mathrm{~kg}^{-1}$ for the dissociation constant for $25^{\circ} \mathrm{C}$. 
Combining cells (B) and (C) gives $0.96679 \mathrm{~V}$ for the cell:

(-) $\mathrm{Cd}-\mathrm{Hg}(11 \%)|| \mathrm{CdSO}_{4}(a=1)\left|\mathrm{Hg}_{2} \mathrm{SO}_{4}(\mathrm{~s})\right|$

$$
\operatorname{Hg}(1)(+)
$$

which is the cadmium sulfate standard cell but for a $\mathrm{CdSO}_{4}$ solution having an activity of one rather than for a saturated solution of $\mathrm{CdSO}_{4}$. This emf may be converted to that for a saturated solution of $\mathrm{CdSO}_{4}$ using the Nernst equation:

$$
E_{\text {standard cell }}=E_{\text {standard cell }}^{0}-\frac{R T}{F} \ln m_{\mathrm{CdSO}_{4}} \gamma_{\mathrm{CdSO} 4}
$$

where

$E_{\text {standard cell }}^{0}=0.96679 \mathrm{~V}$, given above, $m$ is the molality of a saturated solution of $\mathrm{CdSO}_{4}, 3.6789$ [6], $\gamma$ is the mean stoichiometric activity coefficient of $\mathrm{CdSO}_{4}$, and $R, T$, and $F$ have the significance given previously in this paper. Harned and Owen [74] and Robinson and Stokes [75] list values of $\gamma$ from 0.1 to 3.5 molal. Fitting averages of their values above $2 \mathrm{~m}$ $(\gamma$ goes through a minimum at $2.5 \mathrm{~m})$ to an equation of the form:

$$
\log \gamma=\frac{-4 A \sqrt{I}}{1+1.5 \sqrt{I}}+a I+b I^{2}+c I^{3}
$$

where $A=0.5108[76]$ and $I=$ ionic strength, gives:

$\log \gamma=\frac{-2.0432 \cdot \sqrt{I}}{1+1.5 \sqrt{I}}-0.10780 I$

$$
+0.0091117 I^{2}-0.00020852 I^{3}
$$

where coefficients $a, b$, and $c$ were obtained by the method of least squares. This equation yields 0.03646 for $\gamma$ for a saturated solution of $\mathrm{CdSO}_{4}$ at $25{ }^{\circ} \mathrm{C}$. Substituting this value in eq (36) together with the above values for $m$ and $E^{0}$ leads to $1.01840 \mathrm{~V}$ for a "neutral" standard cell of the saturated cadmium sulfate type at $25{ }^{\circ} \mathrm{C}$ which agrees remarkably well with the observed value, $1.0184185 \mathrm{~V}$, see table 3 . This agreement is remarkable since the emfs used in obtaining $E^{0}$ were measured to only $0.01 \mathrm{mV}$.

Another approach to the emf of the standard cell of the saturated cadmium sulfate type may be made using a combination of the three cells:

$$
\text { (-) } \mathrm{Cd}-\mathrm{Hg}(11 \%)\left|\mathrm{CdCl}_{2}(\mathrm{sol})\right| \mathrm{AgCl}(\mathrm{s}) \mid
$$

$$
\operatorname{Ag}(\mathrm{s})(+)
$$

(+) $\mathrm{Ag}(\mathrm{s})|\operatorname{AgCl}(\mathrm{s})| \mathrm{HCl}(\mathrm{sol}) \mid \mathrm{H}_{2}(\mathrm{~g}), \mathrm{Pt}(-)$

(-) $\mathrm{Pt}, \mathrm{H}_{2}$ (g) $\mid \mathrm{H}_{2} \mathrm{SO}_{4}$ (sol) $\mid \mathrm{Hg}_{2} \mathrm{SO}_{4}$ (s) $\mid$

$$
\operatorname{Hg}(1)(+)
$$

where $g=$ gas and the other symbols have the significance given above. The emfs of these cells were measured for a series of concentrations and temperatures by Harned and Fitzgerald [77], Harned and Ehlers [78], and Harned and Hamer [79], respectively. For the first two cells, the authors obtained the standard potential, $E^{0}$, of the cells directly by standard extrapolations using the Debye-Hückel [80] theory of interionic attraction. For the third cell, however, owing to the very high solubility of $\mathrm{Hg}_{2} \mathrm{SO}_{4}$ in dilute solutions of sulfuric acid, the authors calculated $E^{0}$ using values of the activity coefficients of $\mathrm{H}_{2} \mathrm{SO}_{4}$ obtained from emf measurements of the cell [81]:

$$
\begin{array}{r}
\text { (-) } \mathrm{Pt}, \mathrm{H}_{2}(\mathrm{~g})\left|\mathrm{H}_{2} \mathrm{SO}_{4}(\mathrm{sol})\right| \mathrm{PbSO}_{4}(\mathrm{~s}) \mid \mathrm{PbO}_{2}(\mathrm{~s}), \\
\mathrm{Pt}(+)
\end{array}
$$

The authors measured the emfs of cells $(\mathrm{E}),(\mathrm{F}),(\mathrm{G})$, and $(\mathrm{H})$ in international volts and for extrapolations to $m=0$ to obtain $E^{0}$, used the values of the physical constants then in use [82]; their results were converted here to absolute volts using the factor given above, and the presently recommended values for the physical constants [1] were used in the extrapolations to $m=0$ to obtain values of $E^{0}$. For $25{ }^{\circ} \mathrm{C}$, the $E^{0}$ values of cells $(\mathrm{E}),(\mathrm{F})$, and $(\mathrm{G})$ thus obtained are $0.57399 \mathrm{~V},{ }^{13}$ $0.22247 \mathrm{~V}$, and $0.61536 \mathrm{~V}$, respectively. These lead to $0.96688 \mathrm{~V}$ for cell (D) whereas the first method using cells (B) and (C) leads to $0.96679 \mathrm{~V}$; this is not a bad agreement considering that the second method involves three different cells, one of which contains an incompletely dissociated electrolyte, $\mathrm{CdCl}_{2}$, and another involves indirect calculations using a combination of results on two cells, cells $(\mathrm{G})$ and $(\mathrm{H})$. This latter value gives $1.01849 \mathrm{~V}$ for the emf of the standard cell of the saturated cadmium sulfate type at $25{ }^{\circ} \mathrm{C}$. The agreement here with the observed emf is not as good as in the first case, but is still within the probable error of the measurements; more is given later on this agreement.

The emfs of cells $(\mathrm{E}),(\mathrm{F}),(\mathrm{G})$, and $(\mathrm{H})$ have been measured by others. Horsch [84], Lucasse [85], Quintin [86], and Treumann and Ferris [87] measured the emfs of cell $(E)$ at a series of concentrations, except that Horsch used a 4.6-percent amalgam and Lucasse, one of unstated percentage. When Horsch's emfs are corrected from 4.6 percent to 11 percent amalgam by adding $0.00293 \mathrm{~V}$, derivable from Smith's [36] measurements, his results agree closely on the average with the results of Harned and Fitzgerald, except below 0.00025 molal where Horsch stated that his results deviated from a smooth curve. Lucasse's amalgams

\footnotetext{
13 Harned and Fitzgerald' [77] gave 0.57390 international volt for $E^{0}$ (a typographical error listed this as 0.57300 international volt) based on a dissociation constant of $0.011 \mathrm{~mol}$ $\mathrm{kg}^{-1}$ for the equilibrium: $\mathrm{CdCl}^{+} \rightleftharpoons \mathrm{Cd}^{++}+\mathrm{Cl}^{-}$and $5 \AA$ for the ion-size parameter in treating interionic attraction; they assumed that the dissociation: $\mathrm{CdCl}_{2} \rightarrow \mathrm{CdCl}^{+}+\mathrm{Cl}^{-}$was com plete. Their $E^{0}$ value becomes 0.57409 absolute volts using the factor between international and absolute volts given above. They stated their experimental accuracy to be of the order of $0.1 \mathrm{mV}$. Using more recent values for the physical constants [1] and $T[1]$ and the dielectric constant of water [73] it was found that a better fit to their data was obtained using $0.010 \mathrm{~mol} \mathrm{~kg}^{-1}$ for the dissociation constant and $7 \AA$ for the ion-size parameter; these lead 10 0.57399 absolute volt for $E^{0}$. Incidentally, Reghellato and Davies [83] obtained 0.0101 mol $1^{-1}$ for the dissociation constant from electrolytic conductivity measurements.
} 
apparently were $1 \frac{1}{2}$ percent in cadmium since, if the difference in the potentials between $1 \frac{1}{2}$ - and 11-percent amalgams is added to Lucasse's emfs they then agree excellently with those of Harned and Fitzgerald at all concentrations above $0.01 \mathrm{~m}$; however, Lucasse's measurements were not made to sufficiently low concentrations to afford an evaluation of $E^{0}$. Quintin's emfs agree closely with those of Harned and Fitzgerald; her emfs yield $0.57395 \mathrm{~V}$ for $E^{0}$ for cell $(\mathrm{E})$, or $0.04 \mathrm{mV}$ lower than the value obtained from the measurements of Harned and Fitzgerald. Quintin's value for $E^{0}$ gives $0.96683 \mathrm{~V}$ for cell (D) which yields with the $E^{0}$ values for cells $(\mathrm{F})$ and $(\mathrm{G})$ a value of $1.01844 \mathrm{~V}$ for the standard cell of the saturated cadmium sulfate type. This value agrees better with the observed emf of a standard cell than the data of Harned and Fitzgerald. However, the standard deviation of the mean of Quintin's measurements is $0.12_{8} \mathrm{mV}$ as compared with $0.03_{4}$ $\mathrm{mV}$ for Harned and Fitzgerald's results.

The emf of cell $(\mathrm{F})$ has been measured by others in addition to the one cited above. For $E^{0}$ at $25^{\circ} \mathrm{C}$ Prentiss and Scatchard [88] arrived at a value of $0.22250 \mathrm{~V}$ from the earlier measurements excluding those of Harned and Ehlers [78]. MacInnes [89] gave 0.22258 V, Hamer [90] 0.22239 V, Harned and Paxton [91] 0.22239 V, and Bates and Bower [92] 0.22234 V; where necessary these were converted to absolute volts using the factor between international and absolute volts given above. The differences in these values are generally attributed to the differences in the methods of preparation of the silver-silver chloride electrodes or methods of extrapolation to $m=0$ [88]. The average of these values, namely, $0.22244 \mathrm{~V}$ agrees within $0.03 \mathrm{mV}$ of the value of Harned and Ehlers, used above. Since Harned and Fitzgerald for cell (E) and Harned and Ehlers for cell (F) used silver-silver chloride electrodes prepared in the same way, the characteristics of the silver-silver chloride electrode should be eliminated if we use their $E^{0}$ values in arriving at $E^{0}$ for cell (D) since we take the difference of cells $(\mathrm{E})$ and $(\mathrm{F})$ in arriving at $E^{0}$ for cell (D).

The emfs of cell $(\mathrm{G})$ have been measured by many in addition to those cited above [79]. Results are listed in table 10. Those marked with a superscript $b$ were calculated here; the authors did not give values for $E^{0}$. The value of Harned and Hamer when combined with the $E^{0}$ value for the cadmium-amalgam electrode and the $m$ and $\gamma$ of saturated $\mathrm{CdSO}_{4}$ yields an emf for the standard cell of the saturated cadmium sulfate type that agrees well with the observed emf. The average of the values of Harned and Sturges [98], Randall and Stone [101], Trimble and Ebert [102], Müller and Reuther [104], and Beck et al., namely, 0.61555 V (or $0.61551 \mathrm{~V}$, see footnote e of table 10) agrees within 0.19 (or 0.15 ) $\mathrm{mV}$ of the value of Harned and Hamer.

The recent values for $E^{0}$ for cell $(\mathrm{G})$ of Beck, Dobson, and Wynne-Jones [105] and of Covington, Dobson, and Wynne-Jones [69] are not in good agreement, differing by $0.31 \mathrm{mV}$; the first [105] agrees fairly closely with earlier value of Harned and Hamer [79] whereas the latter [69] agrees fairly well with the very early value of Lewis and Lacey [95]. However, when combined with the $E^{0}$ value of the cadmium-amalgam electrode and
TABLE 10. Values of the standard potential of the mercury-mercurous sulfate electrode and of the standard cell $(\mathrm{a}=1)$ and the corresponding electromotive force of the saturated standard cell at $25^{\circ} \mathrm{C}$

\begin{tabular}{|c|c|c|c|c|}
\hline \multicolumn{5}{|c|}{ (all values on $V_{69}$ scale) } \\
\hline \multirow{2}{*}{ Date } & \multirow{2}{*}{ Experimenters } & \multirow{2}{*}{$\frac{\begin{array}{c}\mathrm{Hg} . \\
\mathrm{Hg}_{2} \mathrm{SO}_{4}\end{array}}{\mathrm{E}^{0}}$} & \multicolumn{2}{|c|}{ Standard cell } \\
\hline & & & $E^{0}$ & $E$ (sat.) \\
\hline & & Volt & Volt & Volts \\
\hline 1910 & Brønsted [93]. & a, b 0.6170 & 0.96843 & 1.02004 \\
\hline 1914 & Lewis and Lacey [95]. & 6129 & .96433 & 1.01594 \\
\hline 1918 & 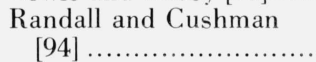 & ${ }^{\mathrm{c}} .6215$ & .97293 & 1.02454 \\
\hline 1921 & $\begin{array}{c}\text { Ferguson and France } \\
{[97] \ldots \ldots \ldots \ldots \ldots \ldots \ldots}\end{array}$ & b. 6199 & .97133 & 1.02294 \\
\hline 1925 & $\begin{array}{l}\text { Harned and Sturges } \\
\quad[98] \ldots \ldots \ldots \ldots \ldots \ldots \ldots \ldots \ldots\end{array}$ & b 61534 & .96677 & 1.01838 \\
\hline 1926 & Ak kerlöf $[99] \ldots \ldots \ldots \ldots$ & b.6168 & .96823 & 1.01984 \\
\hline 1927 & $\begin{array}{l}\text { Randall and Langford } \\
{[100] \ldots \ldots \ldots \ldots \ldots \ldots \ldots}\end{array}$ & d. 6245 & .97593 & 1.02754 \\
\hline 1929 & Randall and Stone $[101] .$. & b. 61550 & .96693 & 1.01854 \\
\hline 1933 & Trimble and Ebert [102].. & b.6156 & .96703 & 1.01864 \\
\hline 1933 & $\begin{array}{l}\text { MacDougall and Blumer } \\
\quad[103] \ldots \ldots \ldots \ldots \ldots \ldots \ldots \ldots \ldots\end{array}$ & .6294 & .98083 & 1.03244 \\
\hline 1935 & Harned and Hamer [79].. & .61536 & .96679 & 1.01840 \\
\hline 1942 & $\begin{array}{l}\text { Müller and Reuther } \\
\quad[104] \ldots \ldots \ldots \ldots \ldots \ldots\end{array}$ & .6155 & .96693 & 1.01854 \\
\hline 1960 & $\begin{array}{l}\text { Beck, Dobson, and } \\
\text { Wynne-Jones [105]. }\end{array}$ & е.61582 & .96725 & 1.01886 \\
\hline 1965 & $\begin{array}{l}\text { Covington, Dobson, and } \\
\text { W }_{\text {ynne-Jones }}[69] \ldots \ldots .\end{array}$ & .61251 & .96394 & 1.01555 \\
\hline 1969 & $\begin{array}{l}\text { Gardiner, Mitchell. and } \\
\text { Cobble }[67] \ldots \ldots \ldots \ldots \ldots \ldots\end{array}$ & ${ }^{\mathrm{f}} .61251$ & .96394 & 1.01555 \\
\hline 1970 & $\begin{array}{c}\text { Sharma and Prasad } \\
{[107] \ldots \ldots \ldots \ldots \ldots \ldots}\end{array}$ & 6135 & .96493 & 1.01564 \\
\hline
\end{tabular}

Observed emf of standard cell ${ }^{\mu}=1.0184186$

a See Randall and Cushman [94]; these authors reported neces. sary corrections for Brønsted's data and reported some earlier results of Arthur Edgar who, however. measured his emfs only to $1 \mathrm{mV}$.

b Calculated here from emfs for 0.05 to $0.21 \mathrm{~m}$ using activity coefficients of sulfuric acid given in reference [79].

c Given in Lewis and Randall [96].

d Stated to be a provisional value.

Ives and Smith [106] listed this value as $0.61560 \mathrm{~V}$-becomes $0.61561 \mathrm{~V}$ on $\mathrm{V}_{69}$ scale; reason for discrepancy is unknown.

${ }^{f}$ Selected by these authors in a recalculation of the activity coefficients of sulfuric acid. i.e.. the 1965 value.

${ }^{*}$ For dc-electrolytic mercurous sulfate exclusively $1.0184354 \mathrm{~V}$.

the $m$ and $\gamma$ of saturated cadmium sulfate, the $E^{0}$ value of Covington et al. for the mercury-mercurous sulfate electrode yields a value for the emf of the standard cell of the saturated cadmium sulfate type which is at great variance $(-3.3 \mathrm{mV})$ from the observed value. There can be little doubt that their $E^{0}$ value for the mercury-mercurous sulfate electrode is in error. The value of Beck et al. for $E^{0}$ of the mercury-mercurous sulfate electrode leads to a better value for the emf of the standard cell of the saturated cadmium sulfate type than does that of Covington et al., but even so yields a value that is about $0.45 \mathrm{mV}$ above the observed value.

These additional $E^{0}$ values for cells $(\mathrm{E}),(\mathrm{F})$, and $(\mathrm{G})$ show that the original selection of data [77-79] for these three cells is justified. The slight difference of $0.09 \mathrm{mV}$ in the calculated value of the emf of the 
standard cell of the saturated cadmium sulfate type as given by cells (B) and (C) on the one hand and by cells $(\mathrm{E}),(\mathrm{F})$, and $(\mathrm{G})$ on the other hand can be attributed largely to uncertainties in extrapolations to obtain $E^{0}$ values, especially for cell $(\mathrm{E})$ wherein cadmium chloride may show more complex dissociation [108] than assumed by Harned and Fitzgerald. The total uncertainty of $0.09 \mathrm{mV}$ is, therefore, attributed entirely to cell $(\mathrm{E})$, which is within the uncertainty stated by the authors.

The $E^{0}$ for the positive electrode of the standard cell is obtained directly from cell $(G),{ }^{14}$ while the $E^{0}$ for the negative electrode of the standard cell is obtained from the $E^{0}$ 's of cells $(\mathrm{B}),(\mathrm{C})$, and $(\mathrm{G})$, or $E_{B}+E_{C}-E_{G}$. These give:

\begin{tabular}{|c|c|}
\hline & $E^{0}, \mathrm{~V}$ \\
\hline 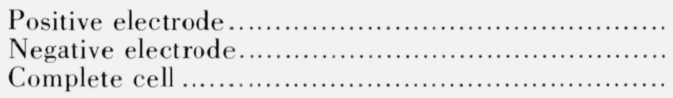 & $\begin{array}{r}0.61536 \\
-0.35143 \\
0.96679\end{array}$ \\
\hline
\end{tabular}

which give for a saturated solution of cadmium sulfate (assuming that $\gamma_{\mathrm{Cd}^{++}}=\gamma_{\mathrm{SO}_{4}}=\gamma_{\mathrm{CdSO}_{4}}$ ):

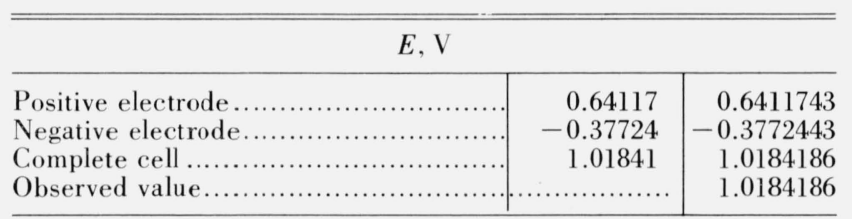

As a basis for measurement, the difference of $8.6 \mu \mathrm{V}$ between the calculated and observed value for the complete cell may be divided between the values for the two electrodes to give the values in the last column.

\section{Reproducibility}

The good check between calorimetric and equilibrium data and emf data of standard cells of the saturated cadmium sulfate type on the one hand and between emf data on galvanic cells related to the standard cell and the emf of the standard cell itself on the other hand, given above, does not imply that standard cells having the emfs given above to $0.1 \mu \mathrm{V}$ (see table 3 ), can be made easily and readily without great care. Cells can be made, however, without extreme care that will agree in emf to $0.01 \mathrm{mV}$ as illustrated by data in table 3 .

Various reasons have been advanced why standard cells cannot be made that agree in emf to $0.1 \mu \mathrm{V}$. The main reasons are: (1) differences in acidity of the solution, (2) differences in acidity between the two distinct electrodes of the cell, (3) differences in extent of reactions between the solution and the cell container (glass), (4) differences in the size of crystals of both cadmium and mercurous sulfates, (5) undersaturation or oversaturation with cadmium sulfate at either one or both of the electrodes, (6) undersaturation of the solution with mercurous sulfate at the positive electrode,

${ }^{14}$ As stated earlier, data from cell $(\mathrm{H})$ are required to get $E^{0}$ for cell $(\mathrm{G})$
(7) presence of mercuric ions at the positive electrode, (8) amalgam composition, (9) impurities, and (10) cell construction. Of these the ones relating to acidity are the most important; amalgam composition, saturation of the solution with cadmium sulfate at both electrodes and with mercurous sulfate at the positive electrode. crystal size, and amount of mercuric ions can be readily controlled. Also by purification, impurities can be reduced to a minimum; impurities with higher electrical potential than hydrogen must be eliminated. Soluble trace impurities, although they may have no effect on the stability of the cell, may alter the initial emf slightly through a solvent effect affecting the value of the activity coefficient of cadmium sulfate. Thermodynamically, the emf and emf-temperature coefficient are independent of cell construction; however, the rate of attainment of equilibrium after a temperature change can be affected by cell design. The $\mathrm{H}$-form of cell used here and in modern cells permits attainment of temperature equilibrium in relatively short times.

The acidity of the solution and the distribution of the acid throughout the cell affect the emf. Increases in acidity in the cell as a whole decrease the emf of the cell $[5,50,55,109,110]$. Increase in acidity at the negative electrode alone increases the emf of the cell while more acid at the positive electrode alone decreases the emf of the cell [36]; these arise from changes in the potential of the acidified electrode and a liquid-junction potential at the interface of the neutral and acid compartments of the cell. If the acid is confined to the region of the mercury-mercurous sulfate paste the liquid-junction potential will differ from that produced if the acid extends to a region above the paste.

Low concentrations of $\mathrm{H}_{2} \mathrm{SO}_{4}$ (less than $0.1 \mathrm{~N}$ ) affect only slightly the emf-temperature coefficient of the cell $[4,49,54,55]$. The relation between the emftemperature coefficient and the acidity appears to be irregular; more on this will be given in a subsequent paper. Addition of sulfuric acid, through a common-ion effect, decreases the solubility of cadmium sulfate but the total sulfate concentration $\left(\mathrm{SO}_{4}^{=}\right.$ion from $\mathrm{CdSO}_{4}+$ $\mathrm{SO}_{\overline{4}}$ ion from $\mathrm{H}_{2} \mathrm{SO}_{4}$ ) exceeds that of $\mathrm{CdSO}_{4}$ alone. However, the activity coefficient of $\mathrm{CdSO}_{4}$ is decreased by the addition of $\mathrm{H}_{2} \mathrm{SO}_{4}$, so that the activity of $\mathrm{CdSO}_{4}$ in water or in water-sulfuric acid mixtures is nearly constant. High concentrations of $\mathrm{H}_{2} \mathrm{SO}_{4}$, of the order of $1 N$ (or $0.5 \mathrm{M}$ ) increase the emf-temperature coefficient of the cell $[49,50]$. However, concentrations of $\mathrm{H}_{2} \mathrm{SO}_{4}$ this high cause excessive gassing at the cadmium-amalgam electrode and are not used for precision cells.

Even though acid affects the initial emf of standard cells, the long-range stability of the cells is affected only slightly. This is evident from the long-range stability exhibited by standard cells of different acidity maintained at the National Bureau of Standards [5, 111] and from international comparisons of cells of various acidities [112]. In the ultimate, stability in emf is the important criterion in the maintenance of the unit of emf, rather than the actual value of the emf. Thermodynamically, however, the value of the emf is all important, in that it gives a measure of the Gibbs energy change or maximum available energy of the cell, and an 
insight into whether the assigned value is consistent with related thermodynamic quantities.

The author is indebted to Bruce F. Field for writing the computer programs for the emf-temperature equations, to Anna Skapars for making recent checks on the emf-temperature coefficients of standard cells of the saturated cadmium sulfate type, and to Georges Leclerc of the Bureau International des Poids et Mesures for information on the acidity of standard cells submitted to the International Bureau by the various National Laboratories for international comparisons.

\section{References}

[1] New values for the physical constants-recommended by NAS-NRC, Nat. Bur. Stand. (U.S.), Tech. News Bull. 47, No. 10, 195 (1963); Consistent set of physical constants proposed. Chem. and Eng. News 41, No. 46, 43 (Nov. 18, 1963).

[2] Craig, D. N., Hoffman, J. I., Law, C. A., and Hamer, W. J., J. Res. Nat. Bur. Stand. 64A (Phys. and Chem.), No. 5. 381-402 (Sept.-Oct. 1960).

[3] Hamer. W. J., and Craig. D. N., J. Electrochem. Soc. 111, 1434 (1964).

[4] Hamer. W. J., J. Res. Nat. Bur. Stand. (U.S.), 72A (Phys. and Chem.), No. 4. 435-439 (July-Aug. 1968).

[5] Hamer, W. J., Standard cells, their construction. maintenance. and characteristics. Nat. Bur. Stand. (U.S.), Monogr. 84. 40 pages (1965).

[6] Brickwedde. L. H., J. Res. Nat. Bur. Stand. (U.S.), 36, 377-388 (1946) RP1707.

[7] Cohen. E., Helderman. V. D., and Moesveld, A. L. Th.. Z. physik. Chem. 96, 259 (1920).

[8] Richards, T. W., and Tamaru. S., J. Am. Chem. Soc. 44, 1060 (1922).

[9] Thomsen, H. P. J. J., Thermochemische unter suchungen, Vo. I-IV, Barth. Leipzig (1882-86).

[10] Kelley, K. K., Contributions to the data on theoretical metallurgy. XIII. High-temperature heat-content, heat-capacitv, and entropy data for the elements and inorganic compounds. Bull. 584. Bur. Mines, 1960.

[11] Pitzer, K. S., and Brewer, L., Lewis and Randall Thermodynamics (McGraw-Hill Book Comp., Inc.. New York. N.Y. 1961).

[12] Bichowsky, F. R., and Rossini, F. D., The thermochemistry of the chemical substances (Reinhold Publishing Corp.. New York. N.Y., 1936).

[13] Varet. R., Ann. chim. phys. (3) 8, 79 (1896).

[14] Giauque, W. F., Barieau, R. E., and Kunzler, J. E., J. Am. Chem. Soc. 72, 5685 (1950).

[15] Parker, V. B., Thermal properties of aqueous uni-univalent electrolytes. Nat. Stand. Ref. Data Ser. Nat. Bur. Stand. (U.S.), 2, 69 pages (Apr. 1965).

[16] Rossini, F. D., J. Res. Nat. Bur. Stand. (U.S.), 9, 679-702 (1932) RP499.

[17] Günther, P., and Wekua, K., Z. physik. Chem. A154, 193 (1931).

[18] Kelley, K. K., Contributions to the data on theoretical metallurgy. X. High-temperature heat-content, heat-capacity, and entropy data for the elements and inorganic compounds, Bull. 476. Bur. Mines, 1949.

[19] Richards, T. W., and Rowe, A. W., J. Am. Chem. Soc. 44, 684 (1922).

[20] Müller, J. A., Bull. soc. chim. (4) 23, 8 (1918).

[21] Papadopoulos, W. N., and Giauque, W. F., J. Am. Chem. Soc. 77, 2740 (1955)

[22] Personal calculation using data of reference [21].

[23] Rossini, F. D., Wagman, D. D., Evans, W. H., Levine, S., and Jaffe, I., Selected values of chemical thermodynamic properties, Nat. Bur. Stand. (U.S.). Circ. 500 (1952).

[24] Wagman, D. D., Evans, W. H., Parker, V. B., Halow, I., Bailey,
S. M., and Schumm, R. H., (a) Selected values of chemical thermodynamic properties, tables for first thirty-four elements in the standard order of arrangement, Nat. Bur. Stand. (U.S.). Tech Note 270-3, 266 pages (Jan. 1968); (b) Selected values of chemical thermodynamic properties, tables for elements 35 through 53 in the standard order of arrangement, Nat. Bur. Stand. (U.S.), Tech. Note 270-4. 151 pages (1965).

[25] Berthelot, P. E. M., Ann. chim. phys. (4) 29, 433 (1873).

[26] Keyes, F. G., Gillespie, L. J.. and Mitsukuri, S., J. Am. Chem. Soc. 44, 707 (1922).

[27] Stull, D. R., and Sinke, G. C.. Thermodynamic properties of the elements, Am. Chem. Soc., Washington, D.C. (1956).

[28] Wexler, A., and Greenspan. L., J. J. Res. Nat. Bur. Stand. (U.S.), 75A (Phys. and Chem.), No. 3, 312-230 (May-June 1971).

[29] Ishikawa, F., and Murooka, H., Bull. Inst. Phys. Chem. Res. (Tokyo) 9, 781 (1933).

[30] Wagman, D. D., Evans, W. H., Halow, I., Parker, V. B., Bailey, S. M., and Schumm, R. H., Selected values of chemical thermodynamic properties, Part 1. Tables for the first twenty-three elements in the standard order of arrangement, Nat. Bur. Stand. (U.S.), Tech. Note 270-1, 127 pages Oct. 1965).

[31] Carpenter, C. D., and Jette, E. R., J. Am. Chem. Soc. 45, 578 (1923).

[32] Holsboer, H. B., Z. physik. Chem. 39, 691 (1902).

[33] Cohen, E., and Moesveld, A. L. Th., Z. physik Chem. 95, 305 (1920).

[34] Hulett, G. A., Trans. Am. Electrochem. Soc. 7, 333 (1905); 15, 435 (1909).

[35] Getman, F. H., J. Am. Chem. Soc. 39, 1806 (1917).

[36] Smith, F. E. (Sir Frank), Proc. Phys. Soc. (London) 22, 11 (1910); Phil. Mag. 19, 250 (1910); Natl. Phys. Lab. Coll. Res. 6, 137 (1910).

[37] Announcement of a change in electrical and photometric units, NBS Circ. 459, 1947.

[38] Nat. Bur. Stand. (U.S.), Tech. News Bull. 52, 204 (1968); 53, 13 (1969).

[39] Parks, W. G., and LaMer, V. K., J. Am. Chem. Soc. 56, 90 (1934).

[40] Hamer, W. J., Inst. Soc. Am., M2-1-Mestind-67, 1967; Proc. Conf. ISA, 22, Part 1, 1 (1967).

[41] Hamer, W. J., Standard cells, Ch. 12, The primary battery, Ed. G. W. Heise and N. C. Cahoon (John Wiley \& Sons, New York, N.Y., 1971).

[42] Wolff, F. A., Trans. Am. Electrochem. Soc. 13, 187 (1908).

[43] Wolff, F. A., Bull. BS 5, 309 (1908).

[44] Wolff, F. A., and Waters, C. E., BS Circ. No. 29 (1910).

[45] Wolff, F. A., Trans. Am. Electrochem. Soc. 5, 49 (1904).

[46] Wolff, F. A., and Waters, C. E., Bull. BS 4, 70 (1907).

[47] International conference on electrical units and standards, Appendix to the report: Notes to the specifications as to the methods adopted in various standardizing laboratories to realize the international ohm and the international ampere, and to prepare the Weston Normal Cell (Darling \& Sons, Ltd., London, 1908).

[48] Vosburgh, W. C., and Eppley, M., J. Am. Chem. Soc. 45, 2268 (1923).

[49] Vosburgh, W. C., J. Optical Soc. Am. \& Rev. Sci. Instr. 12, 511 (1926).

[50] Ishibashi, Y., and Ishizahi, T., Res. Electrotech. Lab. (Tokyo), No. 318 (1931).

[51] Froehlich, M., Z. Instr. 74, 216 (1966); private communication, 1969.

[52] Vincent, G. D., IRE Trans. Instr. I-7, No. 3 and 4, 221 (1958).

[53] Law, C. A., and Skapars, A., results NBS, 1955-70, unpublished.

[54] Vigoureux, P., and Watts, S., Proc. Phys. Soc. (London) 45, $172(1933)$

[55] Obata, J., and Ishibashi, Y., Researches Electrotech. Lab. No. 11, 7 (1921).

[56] Waider, C. W., and Dickinson, H. C., Bull. BS 3, 663 (1907).

[57] NBS Tech. News Bull. 33, No. 3, 28 (1949).

[58] NBS Tech. News Bull. 53, 12 (1969).

[59] Clarke, J., Phys. Today 24, No. 8, 30 (1971).

[60] Driscoll, R. L., and Cutkosky, R. D., J. Res. Nat. Bur. Stand. (U.S.), 60, 297-305 (1958) RP2846.

[61] Cutkosky, R. D., J. Res. Nat. Bur. Stand. (U.S.), 65A (Phys. and Chem.), No. 3, 147-158 (May-June 1961). 
[62] Harned, H. S., and Owen, B. B., The Physical Chemistry of Electrolytic Solutions, 3rd ed., ACS Monograph Series No. 137 (Reinhold Book Corp., New York, N.Y., 1958) p. 428.

[63] Latimer, W. M., The Oxidation States of the Elements and Their Properties in Aqueous Solutions, 2nd ed. (PrenticeHall, Inc., Englewood Cliffs, N.J., 1952).

[64] MacInnes, D. A., The Principles of Electrochemistry (Reinhold Publ. Corp., New York, N.Y., 1939).

[65] Ives, D. J. G., and Janz, G. J., Eds., Reference Electrodes, Theory and Practice (Academic Press, New York, N.Y., 1961).

[66] Brackett, T. E., Hornung, E. W., and Hopkins, T. E., J. Am. Chem. Soc. 82, 4155 (1960).

[67] Gardner, W. L., Mitchell, R. E., and Cobble, J. W., J. Phys. Chem. 73, 2017 (1969).

[68] Beck, W. H., Singh, K. P., and Wynne-Jones, W. F. K., Trans. Faraday Soc. 55, 331 (1959).

[69] Covington, A. K., Dobson, J. V., and Wynne-Jones, W. F. K. Trans. Faraday Soc. 61, 2050 (1965).

[70] Harned, H. S., and Hamer, W. J., J. Am. Chem. Soc. 57, 33 (1935).

[71] LaMer, V. K., and Parks, W. G., J. Am. Chem. Soc. 53, 2040 (1931); 55, 4343 (1933).

[72] Gronwall, T. H., LaMer, V. K., and Sandved, K., Physik. Z. 29 , 358 (1928).

[73] Malmberg, C. G., and Maryott, A. A., J. Res. Nat. Bur. Stand. (U.S.), 56, 1-8 (1956) RP2641.

[74] Reference [62], p. 565.

[75] Robinson, R. A., and Stokes, R. H., Electrolyte solutions, 2nd ed. (Butterworths Sci. Publ., London, 1959) p. 502.

[76] Hamer, W. J., Nat. Stand. Ref. Data Ser. Nat. Bur. Stand. (U.S.), 24, 274 pages (Dec. 1968).

[77] Harned, H. S., and Fitzgerald, M. E., J. Am. Chem. Soc. 58, 2624 (1936).

[78] Harned, H. S., and Ehlers, R. E., J. Am. Chem. Soc. 54, 1350 (1932); 55, 652, 2179 (1933).

[79] Harned, H. S., and Hamer, W. J., J. Am. Chem. Soc. 57, 27 (1935).

[80] Debye, P., and Hückel, E., Physik. Z. 24, 185, 305 (1923).

[81] Hamer, W. J., J. Am. Chem. Soc. 57, 9 (1935).

[82] Reference [62], lst ed., Ch. (5), 1943.

[83] Righellato, E. C., and Davies, C. W., Trans. Faraday Soc. 26, $592(1930)$.

[84] Horsch, W. G., J. Am. Chem. Soc. 41, 1787 (1919).

[85] Lucasse, W. W., J. Am. Chem. Soc. 51, 2597 (1929).

[86] Quintin, Mlle M., Compt. Rendus 200, 1579 (1935).
[87] Treumann, W. B., and Ferris, L. M., J. Am. Chem. Soc. 80 , 5048 (1958).

[88] Prentiss, S. S., and Scatchard, G., Chem. Rev. 13, 139 (1933).

[89] Reference [64], p. 187, table I.

[90] Hamer, W. J., Ph.D. Dissertation, Yale University, New Haven, Conn., 1932.

[91] Harned, H. S., and Paxton, T. R., J. Phys. Chem. 57, 531 (1953).

[92] Bates, R. G., and Bower, V. E. J. Res. Nat. Bur. Stand. (U.S.), 53, 283-290 (1954) RP2546.

[93] Brønsted, J. N., Z. physik. Chem. 68, 693 (1910).

[94. Randall, M., and Cushman, O. E., J. Am. Chem. Soc. 40, 393 (1918).

[95] Lewis, G. N., and Lacey, W. N., J. Am. Chem. Soc. 36, 804 (1914).

[96] Lewis, G. N., and Randall, M., Thermodynamics and the Free Energy of Chemical Substances (McGraw-Hill Book Co. Inc., New York, N.Y., 1923) p. 407.

[97] Ferguson, A. L., and France, W. G.. J. Am. Chem. Soc. 43, 2150 (1921).

[98] Harned, H. S., and Sturgis, R. D., J. Am. Chem. Soc. 47, 945 (1925).

[99] Åkerlöf, G. C., J. Am. Chem. Soc. 48, 1160 (1926).

[100] Randall, M., and Langford, C. T., J. Am. Chem. Soc. 49, 1445 (1927).

[101] Randall, M., and Stone, H. A.. J. Am. Chem. Soc. 51, 1752 (1929).

[102] Trimble, H. M., and Ebert, P. F., J. Am. Chem. Soc. 55, 958 (1933)

[103] MacDougall, F. H., and Blumer, D. R., J. Am. Chem. Soc. 55, 2236 (1933).

[104] Müller, F., and Reuther, H., Z. Electrochem. 48, 220 (1942).

[105] Beck, W. H., Dobson, J. V., and Wynne-Jones, W. F. K. Trans. Faraday Soc. 56, $1172(1960)$

[106] Reference [65], p. 405.

[107] Sharma, L., and Prasad, B., J. Indian Chem. Soc. 47, 379 (1970)

[108] Sahn, G., and Prasad, B., J. Indian Chem. Soc. 46, 233 (1969).

[109] Vosburgh, W. C. J. Am. Chem. Soc. 47, 1265 (1925).

[110] Smith, F. E. (Sir Frank), Natl. Phys. Lab. Report 60, 1920; Dic. App. Phys. 2,268 (1920).

[111] Hamer, W. J., Brickwedde, L. H., and Robb, P. R., Electrochemical Constants, NBS Circ. 524, ch. 12, 1953.

[112] Leclerc, Georges, private communications, 1971.

(Paper 76A3-716) 